\title{
NOVÝ HRAD U KUNRATIC V PRAZE. VÝZKUM A OBNOVA ZANIKAJÍCÍ HRADNÍ STAVBY
}

\author{
JAROSLAV PODLISKA - MATOUŠ SEMERÁD
}

\begin{abstract}
Abstrakt: Nový hrad u Kunratic v Praze je zř́cenina původně královského hradu vystavěného na počátku druhého desetiletí 15. století z podnětu českého a řimského krále Václava IV. Hrad nemél dlouhého trvání. Již v roce 1421 byl dobyt a poničen vojsky husitů. V následující době již nebyl obnoven a postupně se změnil ve zř́ceninu. Vletech $1928-1929$ zde proběhl archeologický výzkum, který odhalil části zaniklých hradnich staveb. Neujasněné odborné kompetence, absence prostředků na dokončení výzkumu a zajištěni odhalených zdiv vedly $k$ zastavení všech praci a k postupnému chátráni celého hradního areálu po dlouhá desetiletí. $V$ letech 2009 až 2013 se uskutečnila první rozsáhlejši údržba areálu v jeho historii a celková konzervace dochovaných staveb. Uskutečněny byly základni archeologické a stavebně historické práce spojené s dokumentaci dochovaných zbytků hradu. Př́spěvek přináši přehled dosavadního badatelského zájmu o lokalitu. Předkládá nová zjištěni archeologie a stavebni historie. Komentuje zkušenosti spojené s obnovou a prezentaci dlouhodobě opomíjené torzálni hradni architektury.
\end{abstract}

Klíčová slova: hrad - archeologický výzkum - operativní průzkum a dokumentace - památková obnova-konzervace.

\section{Nový hrad near Kunratice, Prague: Research into and restoration of a defunct castle structure}

Abstract: The Nový hrad castle near Kunratice, Prague is a ruin of a former royal castle built at the beginning of the second decade of the 15th century by Wenceslas IV, King of Bohemia and the Holy Roman Empire. The castle did not last long: in 1421 it was conquered by the Hussite armies and sustained serious damage. In the years to follow, the castle was not restored and fell into disrepair. Archaeological research into the castle took place in 1928-1929, and in its course some of the former castle buildings were unearthed. Unclear specialist competencies, a lack of means to complete the research and to secure the exposed masonry brought the work to a halt, resulting in the progressive dilapidation of the castle complex stretching over several decades. The first major restoration of the castle was conducted in 2009-2013, and it also involved the overall conservation of the preserved buildings. Basic archaeological excavations and building history work were carried out as well, connected with the documentation of the remaining parts of the castle. This contribution brings an overview of research into the location. It also presents new findings in the area of archaeology and building history, and charts experience associated with the restoration and presentation of long-neglected remains of castle architecture.

Key words: castle - archaeological research - operative research and documentation - heritage restoration-conservation.

\section{Úvod}

Území hlavního města Prahy nepatří z hlediska množství dochovaných hradních staveb $\mathrm{k}$ těm nejvýraznějším. V kontextu pražských měst se vzhledem $\mathrm{k}$ jejich historickému vývoji a významu v minulosti nevytvořila složitější struktura hradních sídel. Vyjma dlouhodobě se formujících panovnických center na Pražském hradě a Vyšehradě pozbyla většina ostatních hradních staveb svou funkci již v průběhu středověku a následně bez viditelných stop zanikla (Durdík 1986). Mezi pražské výjimky, které dosud nezmizely, patří pozůstatky Nového hradu u Kunratic, situované na jihovýchodním okraji hlavního města. Okolnosti jeho vzniku a krátké existence z něj vytvořily objekt, který dlouhodobě přitahuje pozornost nejen specialistů na hradní stavby.

\section{Lokalizace, přírodní rámec a popis objektu}

Zř́icenina Nového hradu u Kunratic se nalézá na zalesněném ostrohu v Kunraticko-michelském lese na katastrálním území městské části Praha-Kunratice (obr. 1). Nadmořská výška jádra bývalého hradu se pohybuje okolo 293 m n.m. Hradní zř́icenina je nemovitou kulturní 


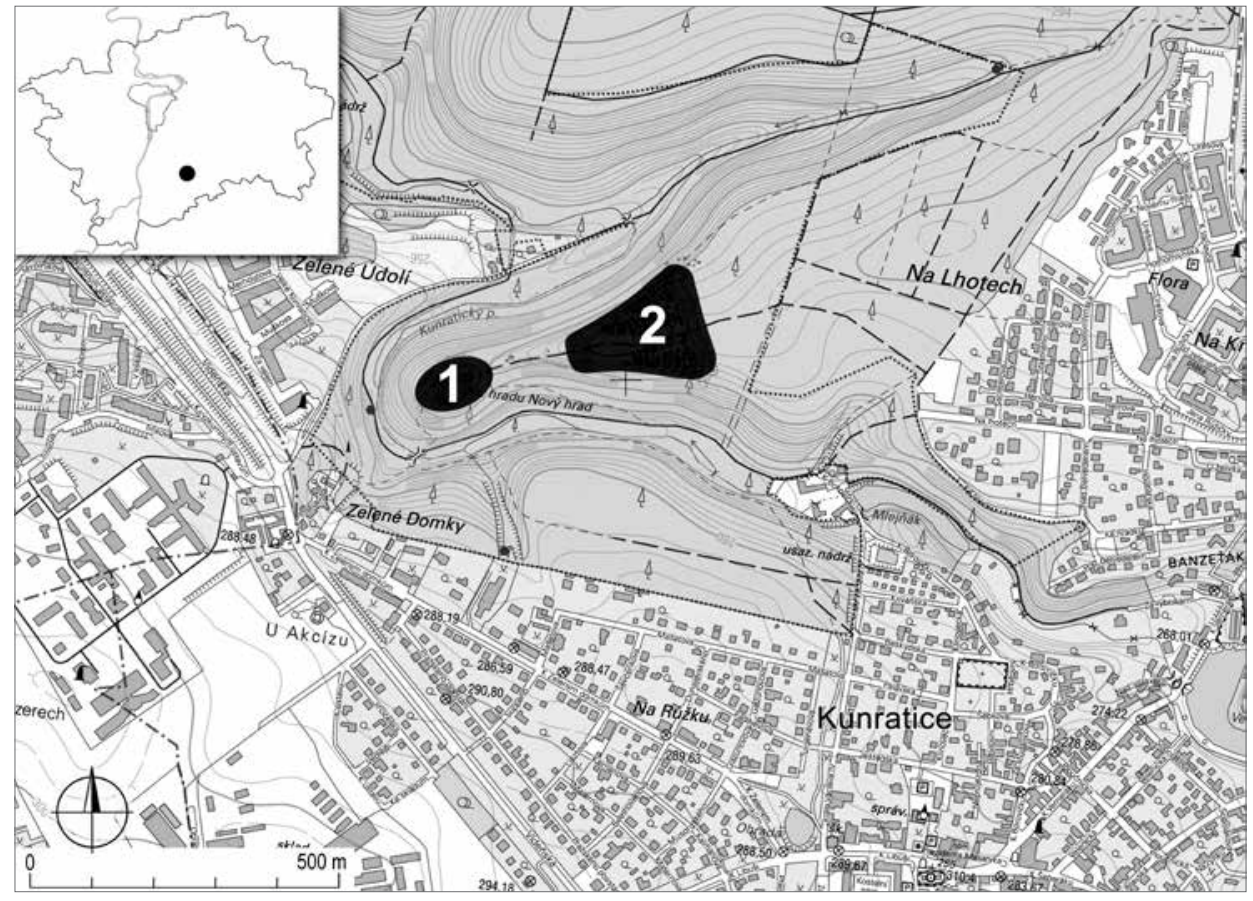

Obr. 1. Nový hrad u Kunratic, k. ú. Praha-Kunratice. 1 - polohová situace hradu, 2 - obléhací tábor Pražanů. Zakresleno do výřezu ze základní mapy České republiky 1:10 000, zdroj ČÚZK Praha. Grafické zpracování J. Hlavatý, NPÚ.

Abb. 1. Wenzelsburg bei Kundratitz, Katastergebiet Prag - Kunratice. 1 - Lageplan, 2 - Belagerungslager der Prager Bürger. Eingezeichnet in einen Ausschnitt der Grundkarte der Republik Tschechien 1:10 000, Quelle Tschechisches Amt für Landesvermessung und Kataster Prag. Grafische Bearbeitung J. Hlavatý, Nationalinstitut für Denkmalpflege.

památkou vedenou v ústředním seznamu kulturních památek pod ev. č. 40793/1-1686 (zř́ícenina a archeologické stopy).

Nový hrad představuje z hlediska vývoje domácí středověké hradní architektury nejmladší hradní stavbu doby krále Václava IV. a poslední královský hrad jeho éry. Hradní stavba zaujala mírně vyvýšené místo na konci mohutného a dlouhého ostrohu vymezeného ze tř́i stran hlubokým údolím Kunratického potoka. Jihovýchodně ca $1 \mathrm{~km}$ od hradu se nalézá obec Kunratice, historické správní centrum. Př́stupová cesta do hradu původně přicházela výhradně od Chodova po širokém hřebenu mírně spadajícím od svého vrcholu do hradního areálu. Strategický význam objektu vyplýval mimo jiné z jeho umístění v blízkosti důležité obchodní cesty směřující z pražských měst na jih Čech. Vzdušná vzdálenost k branám Vyšehradu zde činila necelých $6 \mathrm{~km}$.

Hrad byl od ostatní části hřebene ostrohu oddělen mohutným, do skály vytesaným př́íkopem (obr. 2, 10:1). Na př́íkop navazovalo boční, nejspíše zemní valové opevnění probíhající po obvodu hradního kopce (obr. 2). Dnes má podobu zemního reliktu, dokumentovaného pouze na severní a západní straně ostrohu, místy druhotně překrytého zeminou, případně narušeného trasou recentních stezek a zaniklým lomem na těžbu kamene.

Původně nepravidelný pětiboký hradní areál o rozměrech staveniště ca $70 \times 40 \mathrm{~m}$ se proti ose ostrohu obracel ostrou hranou (břitem) nepodsklepeného nároží palácové stavby (obr. 10:7). Přístupová cesta vedoucí přes most vstoupila do hradu po jeho severní straně, kde mohla teoreticky projít první hradní bránou, po které se však nedochovaly prokazatelné relikty (obr. 10:3). Zde vyústila do prostoru širokého parkánu (předbraní) vymezeného na hraně areálu předpokládanou hradbou, opět nedochovanou a archeologicky neověřenou (obr. 10:4). Cesta dále pokračovala podél severní stěny palácové stavby k druhé hradní bráně (obr. 10:5), kde se ostře 


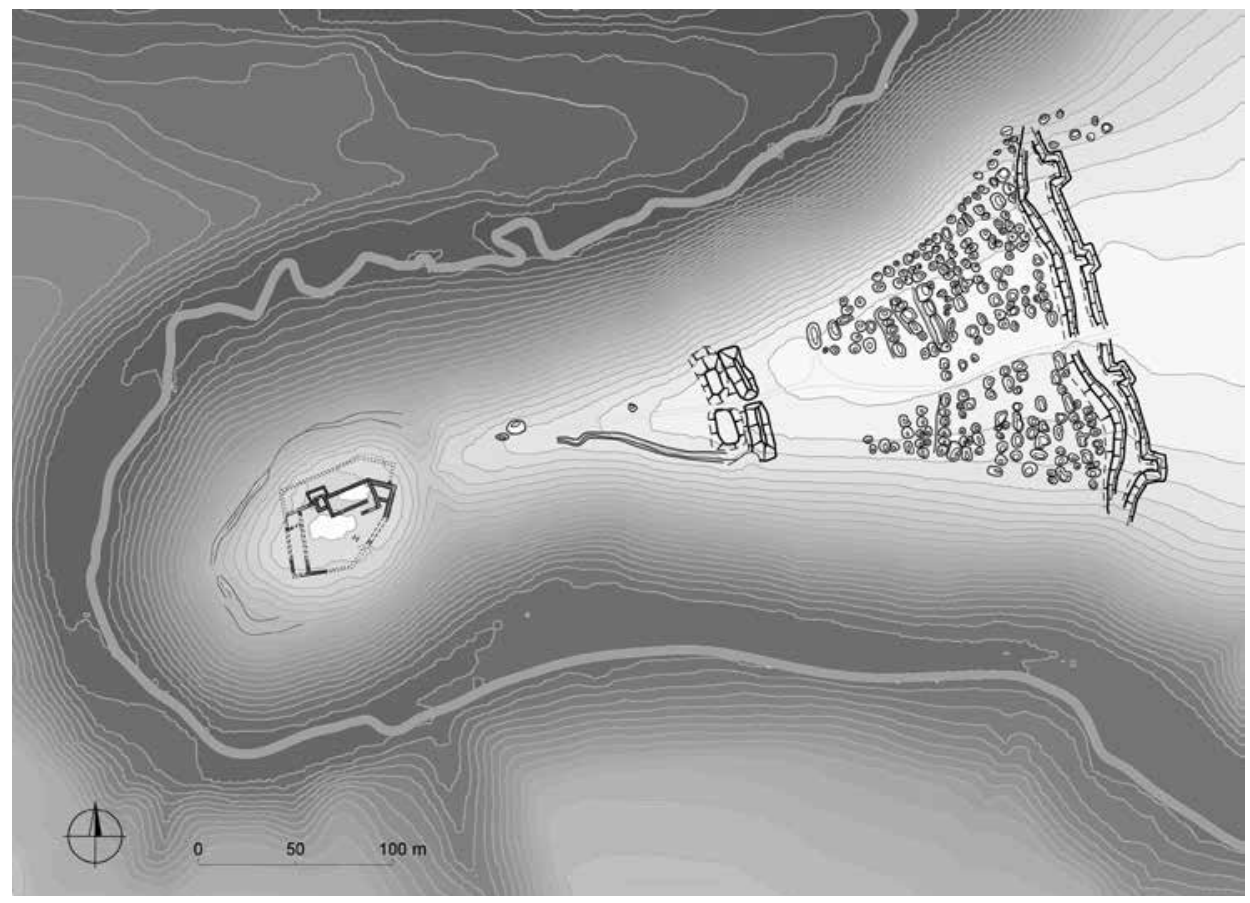

Obr. 2. Nový hrad u Kunratic s táborem obléhatelů. Vrstevnicový plán celkové situace s vyznačením terénních i stavebních reliktů hradu a obléhacího tábora. Geodetické zaměření J. Hlavatý, grafická úprava F. Flek, NPÚ.

Abb. 2. Wenzelsburg bei Kundratitz mit dem Lager der Belagerer. Schichtenplanskizze der Gesamtsituation mit eingezeichneten Gelände- und Baurelikten und Belagerungslager. Geodätische Vermessung J. Hlavatý, grafische Bearbeitung F. Flek, Nationalinstitut für Denkmalpflege.

lomila přes úzký, dosud zachovaný vyzděný příkop, původně překlenutý mostem kolébkové konstrukce do průjezdu vedoucího do prostoru vnitřního nádvoří (obr. 10:11). To bylo ze všech stran obklopeno hradními budovami, z větší části nedochovanými (obr. 10:9, 10). Severní část zaujímal hlavní obdélný velký palác (obr. 10:6), jehož delší osa byla rovnoběžná s osou hradního ostrohu, navazující na západě na druhou hradní bránu, na východě protažena do nepodsklepené stavby s břitem (obr. 10:7). Z hlavního paláce se do současnosti dochoval do skály zahloubený, původně zaklenutý sklep, přístupný po schodištové šíji umístěné na nádvorní straně paláce (obr. 10:8). Zbývající části hradních staveb se již ve větším rozsahu nedochovaly. V současné době se projevují jako osamocená a nekompletní torza zdí, situovaná na jižní a západní straně areálu (obr. 10:9, 10).

Geologický podklad hradního ostrohu je tvořen skalním masivem ordovických sedimentárních hornin třenického a klabavského souvrství (Zavřel 2012, 9-12). Původní rozeklaný povrch ostrožny, ze kterého vystupovaly lavice a skalky odolných prachovců, břidlic a pískovců, byl při výstavbě hradu a jeho opevnění zarovnáván a místy i výrazně odtěžen (hlavně při hloubení prríkopu opevnění na východní straně areálu). Horninový materiál získaný při budování prŕíkopu bezpochyby využili stavitelé hradu jako stavební materiál. Pro kamenicky náročnější prvky architektury posloužily na hrad dovezené druhohorní opuky, patrně z oblasti petř́ínsko-bělohorské pláně, a křídové pískovce, pocházející zřejmě z lomů situovaných v severovýchodním okolí Prahy (Zavřel 2012, 12-14). 


\section{Historie hradu}

Nový hrad u Kunratic náleží z historického hlediska mezi významné hradní stavby doby krále Václava IV. (první nejobsáhlejší zpracování historie hradu Merhout 1912; dosud poslední přehled dějin objektu Záruba 2014, 265-271). Přestože svou existencí patřil mezi stavby krátkodobé, historické děje s ním spojené se vážou k důležitým kapitolám českých středověkých dějin.

Hrad založil na počátku druhé dekády 15. století český a římský král Václav IV. (26. 2. 1361 Norimberk - 16. 8. 1419 Nový hrad u Kunratic) na výhodném ostrohu severně od obce Kunratice, kterou král i s přilehlými pozemky získal do svého vlastnictví v roce 1407 (Merhout 1912,6). Stavba hradu označeného v pramenech „Novum Castrum prope Cunratitz“, př́ípadně „Castro Novo prope Cunraticz“, započala pravděpodobně roku 1411, tak jak nám to dokládají nejstarší stavební smlouvy mezi panovníkem a dodavateli díla (Neuwirth 1893, 604-606; Merhout 1912, 7-8). Ředitelem stavební akce se stal novoměstský měštan Hertvin, jemuž byl podřízen písař Blažej. Vlastní práce měl na starosti mistr Kříž, jehož působení je v této době doloženo mimo jiné i na stavbě Novoměstské radnice v Praze (Menclová 1972, 178). Řada unikátně dochovaných písemností k této stavbě nám dává možnost nahlédnout do organizace výstavby královského hradu, a to i včetně uvedení konkrétních jmen dodavatelů stavby a jejich závazků. K datu 8.6. 1411 se tak ve smlouvě zavazuje zedník Řehoř a jeho bratr Mařík Odrole/Otrole, že před hradem vylámou př́kop 15 loktů hluboký (ca 8,9 m) a 30 loktů široký (ca 17,8 m). Obranyschopnost hradu měl zlepšit rybník či rybníky v údolí - s širokou hrází, k jejíž stavbě se 3. 3. 1412 zavázal Jakub, lamač kamene (AČ XXVI, 576). Stavební materiál v podobě cihel pak v roce 1412 vozil na hrad vozka Mařík (Merhout 1912, 9). Stavební práce musely probíhat velice rychle, protože již na počátku ř́ijna roku 1412 zde král Václav IV. podepisuje první panovnické dokumenty s uvedením místa vystavení „geben zu Newenhus bei Prag“ (AČ VII, 402). Nový hrad se vzhledem ke krátké vzdálenosti od sídelního města patrně stal klíčovým sídlem panovníka, který zde v závěru svého života opakovaně pobýval a taktéž i 16. 8. 1419 zemřel (FRB V, 346; Hlaváček 1962).

Po Václavově smrti hrad krátce využívala jeho manželka Žofie. Jeho bratr císař Zikmund Lucemburský hrad nejméně dvakrát v roce 1420 navštívil (FRB V, 373, 376, 441). Vzhledem ke své strategické poloze v blízkosti sídelního města se hrad na počátku husitských válek stal opěrným vojenským bodem katolické strany stojící na Zikmundově straně. Po nezdařené panovníkově vojenské akci u Vyšehradu v listopadu 1420 byl hrad na sklonku roku oblehnut vojskem Pražanů (30. 12.), kteří si pro tyto účely zř́ídili v jeho těsném předpolí rozlehlý opevněný tábor, jehož terénní pozůstatky se zde nacházejí dodnes. Nasazením několika praků a střelných zbraní se oblehatelům podařilo zničit obranné ochozy hradu, takže již 25. 1. 1421 se posádka vedená Herbortem z Fulštejna vzdala. Krátce nato byl hrad vyrabován, vypálen a z taktických důvodů rozbořen (FRB V, 465-466). Po uvedené události zůstal ve zříceninách a již nikdy nebyl obnoven. V majetkových záznamech v následujícím období již figuruje pouze údaj o zboží kunratickém, které zpočátku patří královské koruně. V průběhu 16. století postupně přechází do majetku různých šlechtických rodů (Merhout 1912, 21-23).

Na počátku 18. století, za tehdejšího majitele kunratického panství Jana Arnošta hraběte z Golče, byla roku 1736 v areálu zříceniny hradu vystavěna pravděpodobně oválná kaple sv. Jana Nepomuckého a při ní zřízena hájovna, ke které směřovala ze západu nová cesta (Merhout 1902, 97-99; 1912, 43-47, 88). Kaple neměla dlouhého trvání, a tak již roku 1787 byla zrušena. Hájovna zde patrně zůstala déle, až do počátku 19. století, kdy byla zbořena.

Zdejší prostor včetně hradu poznamenala v minulosti těžba břidlice, hojně využívané zejména pro brusičské potřeby. O př́itomnosti a kvalitě místního kamene se dozvídáme již v průběhu 17. století u Bohuslava Balbína (Balbín 1986, 159; souhrnně Merhout 1912, 48-49). Těžba na různých místech probíhala intenzivně od druhé poloviny 18 . až do počátku 20. století. Jeden z lomů, kterých se na svazích kunratické ostrožny nalézalo více, zasáhl i jižní část hradního areálu a výrazně jej poničil. Jeho původní rozsah je však dnes blíže neurčitelný, hlavně z důvodu následného zasypání vytěženým materiálem z hradních vykopávek. 
V 19. století se romantické pozůstatky hradu stávají oblíbeným místem návštěv a cílem výletů. Tuto skutečnost, přinášející s sebou škody v lese a plašení zvěře, nesla správa kunratického velkostatku v režii rodiny Korbů $\mathrm{z}$ Weidenheimu velmi nelibě. $Z$ uvedeného důvodu se v roce 1881 rozhodla pro radikální řešení a nechala do té doby stojící obvodové stěny hradních staveb zbořit. V jaké podobě a rozsahu byl hrad v této době zachován, nevíme. Dosud jedinou, avšak interpretačně značně problematickou představu nám přináší kresba hradu z doby okolo roku 1850 od Edvarda Herolda s výraznou dominantou věžové stavby, snad paláce (Durdík 1984, 176). Po demolici staveb získal hradní areál přibližně současnou podobu a je v následujícím období hodnocen jako pamětihodnost velice zpustošená (Sedláček 1927, 235).

V průběhu 20. let 20. století přešel hrad po déletrvajících majetkových převodech do držení města Prahy. Velice záhy po uvedeném aktu je z iniciativy Památkového sboru hlavního města Prahy a za dotace Ministerstva školství a národní osvěty zahájen archeologický výzkum hradu, realizovaný ve dvou výzkumných kampaních v letech 1928 a 1929. Vedením výzkumu byla pověřena tehdy začínající badatelka Libuše Jansová ze Státního archeologického ústavu. Odborný dohled měl na starosti Cyril Merhout, zastupující zde Ministerstvo školství a národní osvěty jako poskytovatele dotace. O průběhu a organizaci výzkumných prací nás dnes informuje dosti nesourodý a dosud detailněji nevyhodnocený konvolut úředních písemností Památkového sboru, Magistrátu hl.m. Prahy a Ministerstva školství a osvěty, uložených ve fondech několika institucí (Národní archiv - Fond státní památkové správy; Ministerstvo školství - Fond Ministerstva školství; Archiv hlavního města Prahy - Fond Památkový sbor hlavního města Prahy; Ústav dějin umění - Fond Rudolfa Hlubinky). Vzrůstající problémy spojené hlavně s neujasněnými odbornými kompetencemi mezi Památkovým sborem a zástupci Ministerstva školství a národní osvěty a dále pak nezajištěné financování vykopávek měly za následek předčasné ukončení prací, přsestože snaha pokračovat zde proklamována byla. Vybrané části odhalených hradních
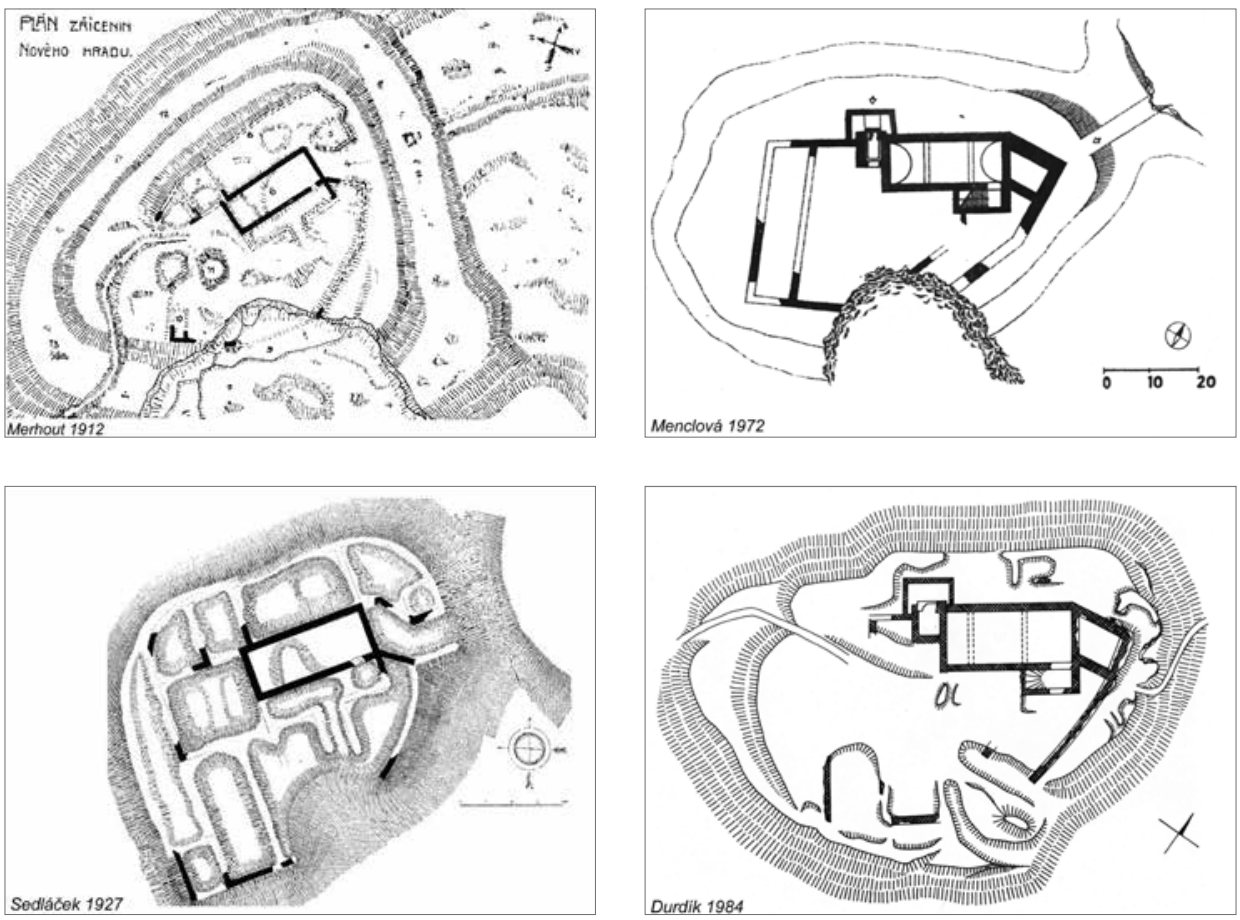

Obr. 3. Nový hrad u Kunratic. Přehled historických plánů hradu. Podle Merhout 1912; Sedláček 1927; Menclová $1972 ;$ Durdík 1984. Abb. 3. Wenzelsburg bei Kundratitz. Übersicht historischer Planskizzen der Burg. Nach Merhout 1912; Sedláček 1927; Menclová 1972; Durdík 1984. 
konstrukcí nechala pražská obec na počátku 30. let 20. století provizorně zajistit. Postupně narůstající nezájem vlastníka hradu a absence následné péče však měly za následek nezadržitelné chátrání odhalených staveb, místy i jejich definitivní zánik. V uvedeném stavu pozůstatky hradu setrvaly až do doby zahájení př́ípravy sanace objektu v roce 2009.

\section{Přehled bádání}

Dějinám a pozůstatkům Nového hradu u Kunratic byla mezi zájemci o panská sídla věnována vždy náležitá pozornost, i přes jeho krátkou dobu existence. Důvodem zde byla především osoba jeho zakladatele a historické děje s ním spojené. Hradu se věnovali nejen historici vycházející z výpovědi písemných pramenů, ale také archeologové a historici architektury, kteří v objektu spatřovali pozoruhodný výtvor hradního stavitelství předhusitského období.

Odborné poznávání hradního areálu v moderním slova pojetí spadá až na počátek 20. století a je spojeno s osobou Cyrila Merhouta. Ve své práci věnované historii Kunratic a okolí se obšírně věnoval i dějinám Nového hradu (Merhout 1912). Na podkladě písemných pramenů představil historický vývoj objektu, jeho stavbu a následný zánik. Samostatnou kapitolu věnoval popisu hradního areálu a jeho funkci. Důležité informace pro rekonstrukci stavby má připojený situační plánek od J. Pázlera, který zachycuje jeho stav ještě před archeologickým odkryvem na sklonku 20. let 20. století (obr. 3). V obdobném duchu představil př́iběh hradu i August Sedláček (obr. 3), který jej publikoval ve své monumentální řadě věnované panským sídlům na našem území (Sedláček 1927, 230-235). Zde připojený situační plánek je převzatý ze staršího Soupisu památek (Podlaha 1908, 94).

V roce 1928 byl zahájen již zmíněný archeologický výzkum Libuše Jansové. Ve dvou výzkumných sezónách byla prokopána podstatná část severní strany hradu zahrnující prostor dru-

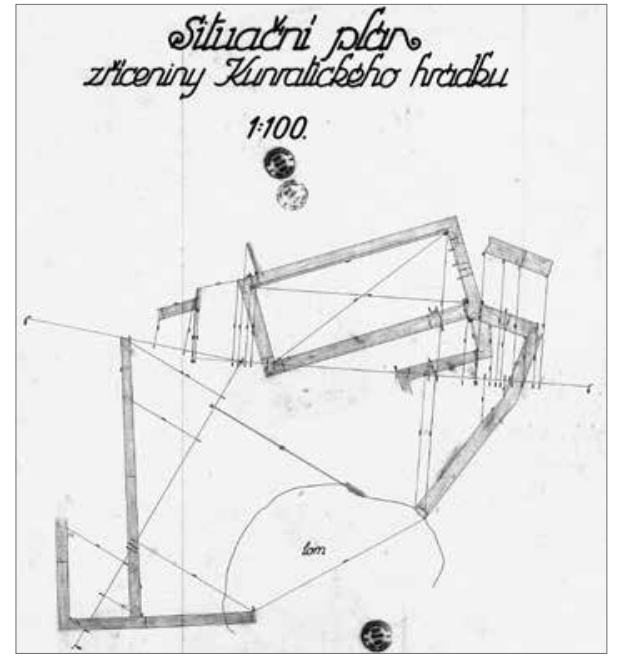

Obr. 4. Archivní plán zř́íceniny Kunratického hrádku (Nového hradu u Kunratic). Stav viditelných konstrukcí hradu před zahájením výzkumu v roce 1928, opatřený razítkem Památkového sboru hlavního města Prahy. Zpracoval pravděpodobně Ing. G. Varvažovský. Uloženo v Archivu hl.m. Prahy, Sbírka map a plánů, neuspořádaná část, bez sign.

Abb. 4. Archivplanskizze mit Ruine der Kleinburg Kundratitz (Wenzelsburg bei Kundratitz). Zustand der sichtbaren Burgkonstruktionen vor Grabungsbeginn im Jahr 1928, versehen mit einem Stempel des Denkmalkomitees der Hauptstadt Prag. Die Bearbeitung stammt wahrscheinlich von Ing. G. Varvažovský. Aufbewahrt im Archiv der Hauptstadt Prag, Karten- und Plansammlung, ungeordneter Teil, ohne Signatur. hé hradní brány a jejího předbraní. Dále pak plochu rozlehlého hlavního paláce se suterénem a př́stupovým schodištěm. Přestože se $\mathrm{v}$ dostupných archivních fondech dochovaly materiály zachycující okolnosti a průběh výzkumu, terénní dokumentace nebo deník vý-

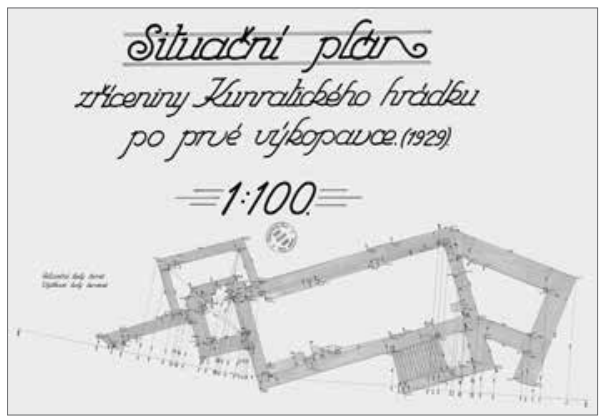

Obr. 5. Archivní plán zř́íceniny Kunratického hrádku (Nového hradu u Kunratic) po prvé vykopávce (1929). Zachycena je situace paláce a druhé brány. Plán je opatřen razítkem Památkového sboru hlavního města Prahy. Zpracoval pravděpodobně Ing. G. Varvažovský. Uloženo v Archivuhl.m. Prahy, Sbírka map a plánů, neuspořádaná část, bez sign.

Abb. 5. Archivplanskizze mit Ruine der Kleinburg Kundratitz (Wenzelsburg bei Kundratitz) nach der ersten Ausgrabung (1929). Dargestellt ist die Lage des Palas und des zweiten Tors. Die Planskizze ist mit einem Stempel des Denkmalkomitees der Hauptstadt Prag versehen. Die Bearbeitung stammt wahrscheinlich von Ing. G. Varvažovský. Aufbewahrt im Archiv der Hauptstadt Prag, Karten- und Plansammlung, ungeordneter Teil, ohne Signatur. 
zkumu jsou doposud nezvěstné. Obdobně tomu bylo i s geodetickými plány lokality a objektu vyhotovenými Ing. Gustavem Varvažovským před a po uskutečnění výzkumu (Durdík 1984, 179). K jejich znovunalezení došlo díky pracovníkům Archivu hlavního města Prahy v roce 2013 (obr. 4, 5). V současné době nám tak průběh a výsledky akce přibližuje společně s plány i soubor dobových fotografií uložený $\mathrm{v}$ archivech několika pražských institucí, z nichž nejvíce jich eviduje Archeologický ústav AV ČR v Praze. Jejich autorství je zčásti připisované Cyrilu Merhoutovi, vyloučit však nelze i podíl jiných autorů. Obdobný osud stihl i vlastní movité nálezy z hradu, ze kterých se do dnešních dnů dochovaly pouze kamenné architektonické články z krbové rrímsy s konzolami, uložené v lapidáriu Národního muzea v Praze. Výzkum po svém ukončení nebyl jeho autorkou nikdy vyhodnocen.

V průběhu druhé poloviny 20. století se odborný zájem obrátil na problematiku obléhacího tábora Pražanů z let 1420 až 1421 (obr. 2), dochovaného v předpolí hradu (Drobná 1953; 1971). Zjištovací archeologický výzkum lokality provedený Zoroslavou Drobnou přinesl důležité informace o podobě tábora, jeho zástavbě a opevnění. Vedle pozoruhodných movitých artefaktů militární povahy, které jsou uloženy ve fondech Národního muzea v Praze, zde byly zjištěny i doklady staršího pravěkého osídlení, zachované v podobě několika sídlištních objektů (jam) a kulturní vrstvy na bázi historického nadloží (Drobná 1953, 199-200). Pro dějiny osídlení hradního ostrohu je důležitá informace, že ve sbírkách téže instituce je z prostoru Nového hradu evidován soubor pravěké sídlištní keramiky kultury knovízské, avšak bez bližší specifikace nálezových okolností (Hartl 1971-1972, 67). Samé problematice vojenského tábora byla v nedávné době věnována studie Jana Kypty a Jaroslava Podlisky, která na podkladě nového geodetického zaměření lokality a současně realizovaného geofyzikálního průzkumu (Křivánek 2014) provedla nové zhodnocení jeho archeologického a památkového potenciálu (Kypta-Podliska 2014).

První moderní zhodnocení stavební podoby hradu se objevilo v syntéze věnované českým hradům od Dobroslavy Menclové (1972, 176-179). Vedle shrnutí písemných pramenů ke stavbě objektu a srovnání jednotlivých komponent s dobovou hradní produkcí publikovala velice věrný půdorysný plán hradu, jehož základem byly podle současného stavu poznání s vysokou pravděpodobností znovuobjevené plány G. Varvažovského (obr. 4, 5).

V téže době zahájil systematické sledování hradního areálu i archeolog Tomáš Durdík z Archeologického ústavu AV ČR v Praze, který zde provedl postupem doby komplexní povrchový průzkum, v jehož rámci v roce 1975 vznikl i zcela nový terénní náčrt situace hradních staveb (obr. 3), následně publikovaný a upravovaný v řadě odborných studií a monografíi (Durdík 1984, 177; 1986; 1999, 389-390). Zhodnocení se dostalo i středověké keramice z hradního areálu získané sběrem, jejíž význam měl vazbu především na stanovení její chronologie ve vazbě na absolutní data hradní stavby (Durdík 1980). Od té doby byl areál zmiňovaným badatelem systematicky sledován a posuzován z hlediska jeho památkového stavu a evidence nelegálních zásahů, případně pozitivních nálezů, o čemž svědčí početné evidenční záznamy v Archeologické databázi Čech, publikované ve Výzkumech v Čechách (celkem 22 hlášení). V průběhu posledních dvou desetiletí byl stav hradu hodnocen jako neuspokojivý, doprovázený neodbornými zásahy do terénů a postupnou degradací dochovaného zdiva hradních staveb a terénních reliktů (mimo jiné vlivem od roku 1934 každoročně pořádaného přespolního běhu Velké kunratické).

Zatím poslední rekapitulace našich znalostí o dějinách hradu a jeho stavebním vývoji pochází od Františka Záruby, jehož práce věnovaná hradům Václava IV. přináší komplexnější srovnání stavby v kontextu dobové hradní produkce (Záruba 2014, 265-271).

\section{Archeologický výzkum - popis nálezové situace}

Projekt památkové údržby a konzervace hradního areálu zahájený v roce 2009 s sebou přinesl i nové představy o jeho komunikačním zpřístupnění. Jedním z požadavků vlastníka a investora akce bylo vybudování nové dřevěné lávky přes hradní příkop, která by umožnila návštěvníkům a údržbě lesa pohodlnější př́ístup do objektu a zároveň eliminovala cesty neznačené, jejichž dlouhodobé použivání mělo negativní dopad na památku samu (eroze a opakované narušování 


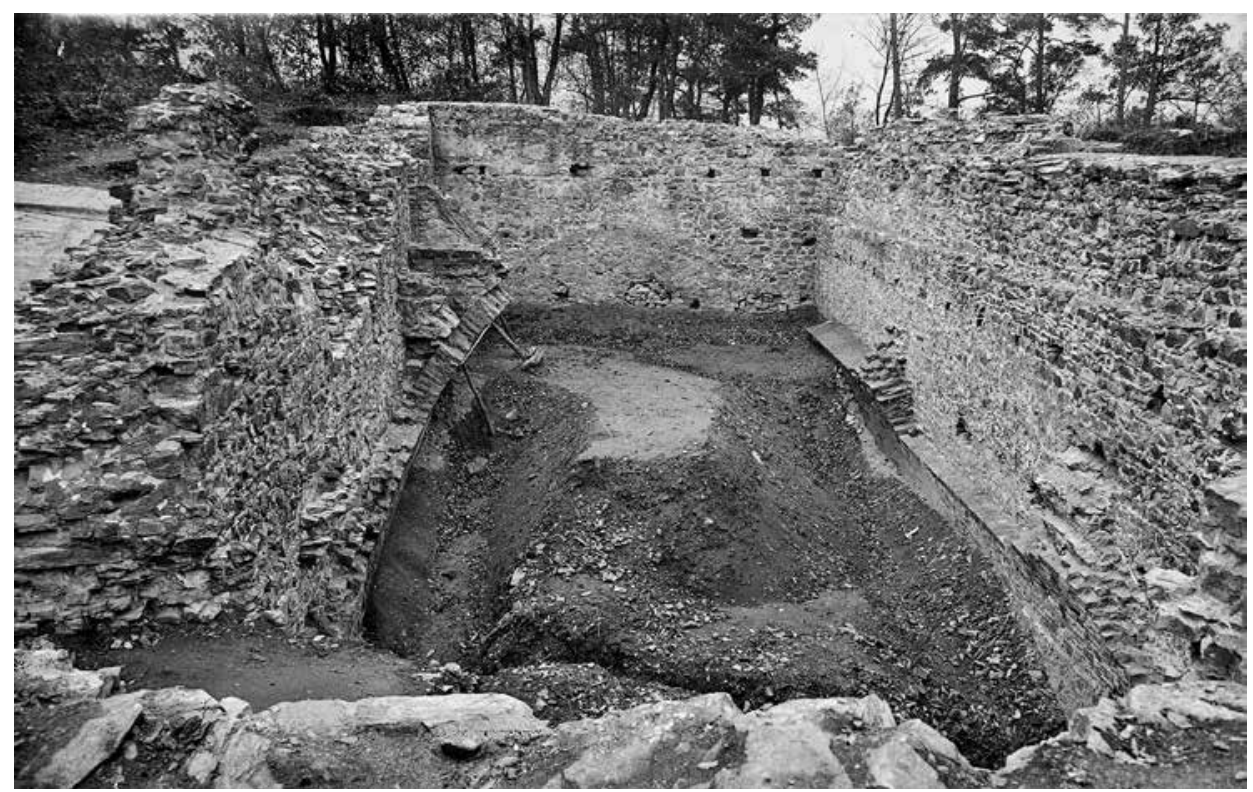

Obr. 6. Nový hrad u Kunratic. Pohled od severovýchodu do suterénu hradního paláce v prủběhu archeologického výzkumu v letech 1928-1929. Na jižní straně zřetelně vystupují dnes již nedochované cihlové náběhy valené klenby s pasy. Archiv fotosbírka NPÚ, N014339.

Abb. 6. Wenzelsburg bei Kundratitz. Blick von Nordosten in das Souterrain des Burgpalas während der archäologischen Grabung von 1928 - 1929. An der Südseite treten deutlich die heute nicht mehr erhaltenen Backsteindienste eines Gurttonnengewölbes hervor. Archiv der Fotosammlung des Nationalinstituts für Denkmalpflege, N014339.

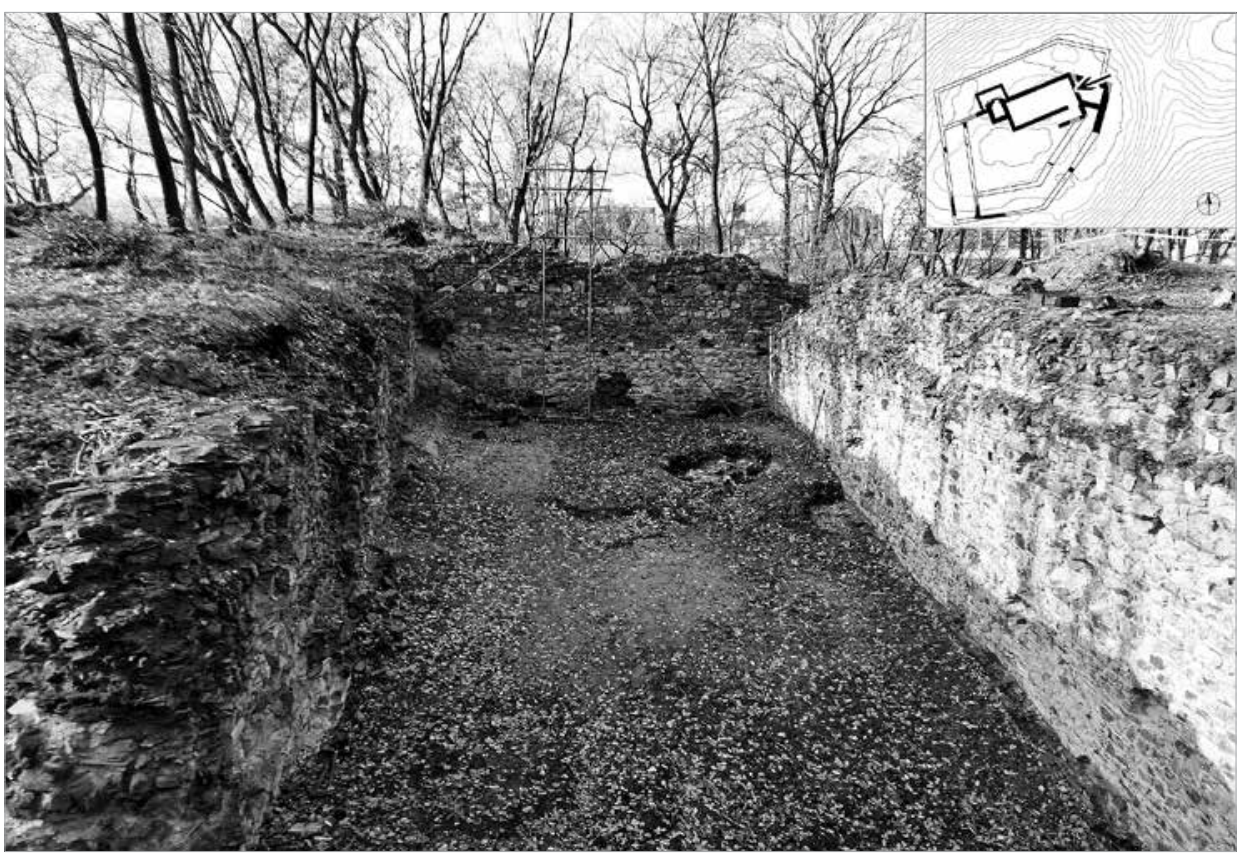

Obr. 7. Nový hrad u Kunratic. Srovnávací foto k obr. 6, stav objektu před zahájením rekonstrukěních prací v roce 2012. Foto F. Flek, NPÚ.

Abb. 7. Wenzelsburg bei Kundratitz. Vergleichsfoto zu Abb. 6, Zustand des Objektes vor Beginn der Rekonstruktionsarbeiten im Jahr 2012. Foto F. Flek, Nationalinstitut für Denkmalpflege. 


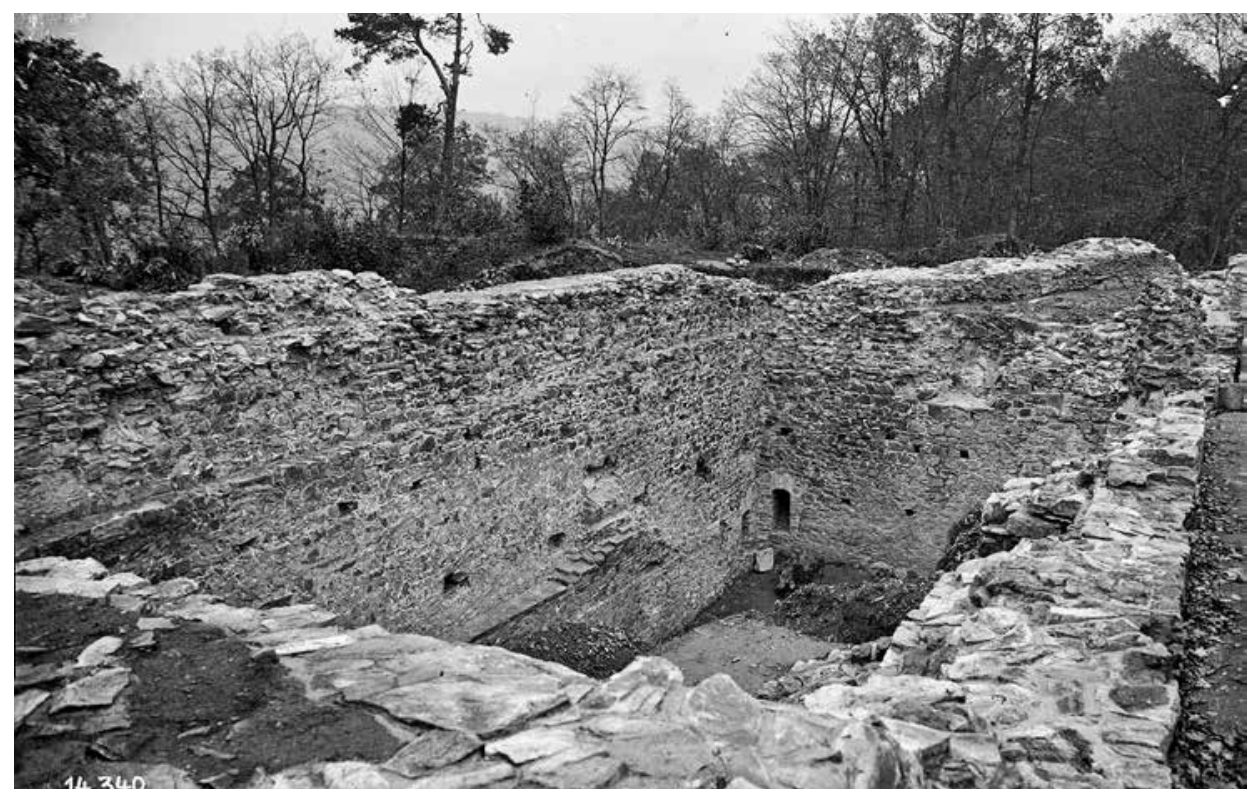

Obr. 8. Nový hrad u Kunratic. Pohled od jihozápadu do suterénu hradního paláce v průběhu archeologického výzkumu v letech 1928-1929. Snímek zachycuje výrazné zahloubení výzkumu na východní straně suterénu. Archiv fotosbírka NPÚ, N014340.

Abb. 8. Wenzelsburg bei Kundratitz. Blick von Südwesten in das Souterrain des Burgpalas während der archäologischen Grabung von 1928-1929. Die Aufnahme zeigt die deutliche Eintiefung der Grabung an der Ostseite des Souterrains. Archiv der Fotosammlung des Nationalinstituts für Denkmalpflege, N014340.

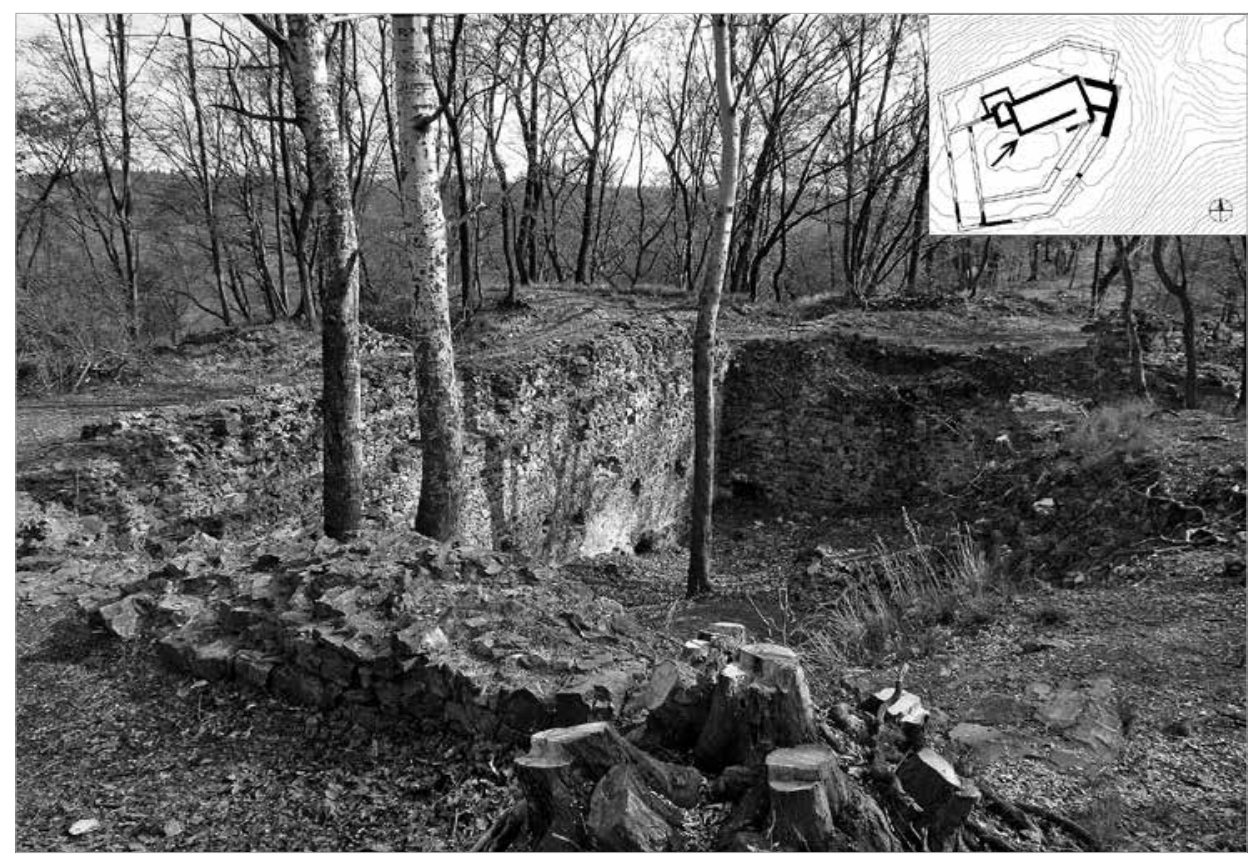

Obr. 9. Nový hrad u Kunratic. Srovnávací foto k obr. 8, stav objektu před zahájením rekonstrukčních prací v roce 2012. Foto F. Flek, NPÚ.

Abb. 9. Wenzelsburg bei Kundratitz. Vergleichsfoto zu Abb. 8, Zustand des Objektes vor Beginn der Rekonstruktionsarbeiten im Jahr 2012. Foto F. Flek, Nationalinstitut für Denkmalpflege. 
terénních reliktů hradu). Nové založení mostu na hraně př́ikopu a dvojice podpůrných pilírů usazených do př́ikopu vyvolala realizaci nevelkého záchranného archeologického výzkumu, jehož cílem bylo v místech stavebních zásahů (výkopů) a sanačních prací prozkoumat a zdokumentovat podobu zasažených antropogenních terénů až na úroveň projektovaného dna stavby (obr. 10). Výzkum byl prováděn standardními odbornými postupy určenými pro archeologický výzkum stratifikovaných terénních situací. Při těchto výzkumech je kladen důraz na vertikální stratigrafii historického nadloží a komplexní zachycení všech podstatných informací, které lze využít pro rekonstrukci všech dějů (především antropogenních), které proběhly v daném místě. Důležitou součástí dokumentace se stal i popis odhalených př́rodních kontextů. Plocha výzkumu byla situována na několika místech hradního areálu, která se svou polohou a původní funkcí výrazně odlišovala. Archeologický výzkum jednotlivých sond a operativní (stavební) dokumentace památky proběhly v návaznosti na postup stavebních prací, místy ve vzájemné koordinaci.

V roce 2012, s pokračováním v roce 2013, proběhly archeologické práce v prostoru hradního př́íkopu a jeho předpolí (obr. 10:2).

\section{Sonda S01}

Archeologická sonda S01 se nalézala na vnější (východní) hraně hradního - šíjového př́ikopu. Šlo o téměř čtvercový výkop o rozměrech ca $4,2 \times 4,8 \mathrm{~m}$. Stávající, erozí silně poznamenaný terén zde tvořila slabě humózní prachovitá hlína s drobnými odštěpky místní horniny (prachovce) o mocnosti kolísající od 2 do $10 \mathrm{~cm}$. Její povrch se svažoval směrem k západu, do př́íkopu (nivelety v rozmezí 290,00 až 290,62 m n. m.). Po jejím mechanickém odstranění se pod ní v celé ploše sondy objevil skalní podklad v různém stupni dochování. Pozůstatky antropogenní činnosti zde doloženy nebyly (Podliska 2012, 28; Flek-Podliska-Semerád 2014, 13).

\section{Sondy S02 a S03}

V místech budoucích podpěr mostu na dně hradního příkopu byly situovány sondy $\mathrm{S} 02$ a S03 (obr. 10). Archeologická sonda S02 se nalézala v jeho východní části. Šlo o obdélný výkop o rozměrech ca $5,1 \times 3 \mathrm{~m}$. Terénní situaci zde tvořily výhradně polohy kamenité sutě přecházející od prachovité hlíny k hrubé frakci u dna sondy. Spodní partie na rozdíl od vrchní obsahovala větší kameny místního původu. Geneticky šlo o svahovou sut' vznikající postupným zvětráváním odkrytého skalního výchozu ze stěn příkopu a ukládající se na dně vyhloubeného př́íkopu. Jediným nálezem zde bylo několik zlomků střešních prejzů. Na nezvětralém skalním podkladu nebyly zastiženy žádné stopy dodatečné úpravy či pozůstatků stavebních konstrukcí (absence malty, negativů základů nosných konstrukcí pro předpokládaný most). Takřka obdobnou situaci se podařilo dokumentovat $\mathrm{v}$ rozměrově podobné sondě $\mathrm{S} 03$, situované $\mathrm{v}$ západní části př́kopu (Podliska 2012, 29-30; Flek-Podliska-Semerád 2014, 14).

Podstatně zajímavější zjištění přinesla skupina sond S04, S05 a S06 situovaná na vnitřní hraně prŕíkopu (obr. 10). Sondy půdorysně tvořily nepravidelný mnohoúhelník o ploše $22,5 \mathrm{~m}^{2}$. $\mathrm{K}$ jejich realizaci došlo postupně v průběhu obou sezón výzkumu.

\section{Sonda S04}

Sonda S04 byla položena v místech terénního reliktu porostlého nízkou vegetací. Pouze lokálně bylo zřejmé, že jde o blíže neurčitelný relikt zděné konstrukce. Po odstranění svrchních vrstev prachovité hlíny s vyšším podílem kořenů a drobnějších kamenů se na větší části plochy objevilo destruované těleso zděné konstrukce tvořené v centrální části šikmo uloženými kameny prostoupenými chudou a výrazně zvětralou vápennou maltou. Po obvodu sondy šlo spíše o volnější polohu kamenů prostoupených zvětralým maltovým pojivem, bez jasnější skladby. Náznak původní konstrukce byl zřetelný především v centrální části sondy, kde bylo možné na nevelkém úseku rozeznat jasnou strukturu řádkování s náznakem líce. Celá konstrukce byla podle způsobu uložení lomových kamenů destruována směrem dovnitř areálu hradu (zřetelné především při pohledu od východu). Koruna kamenné destrukce se pohybovala na maximální niveletě $291,60 \mathrm{mn}$. m. Její měřitelná mocnost činila kolem ca 1,2 m. Destrukce zdi nasedala 


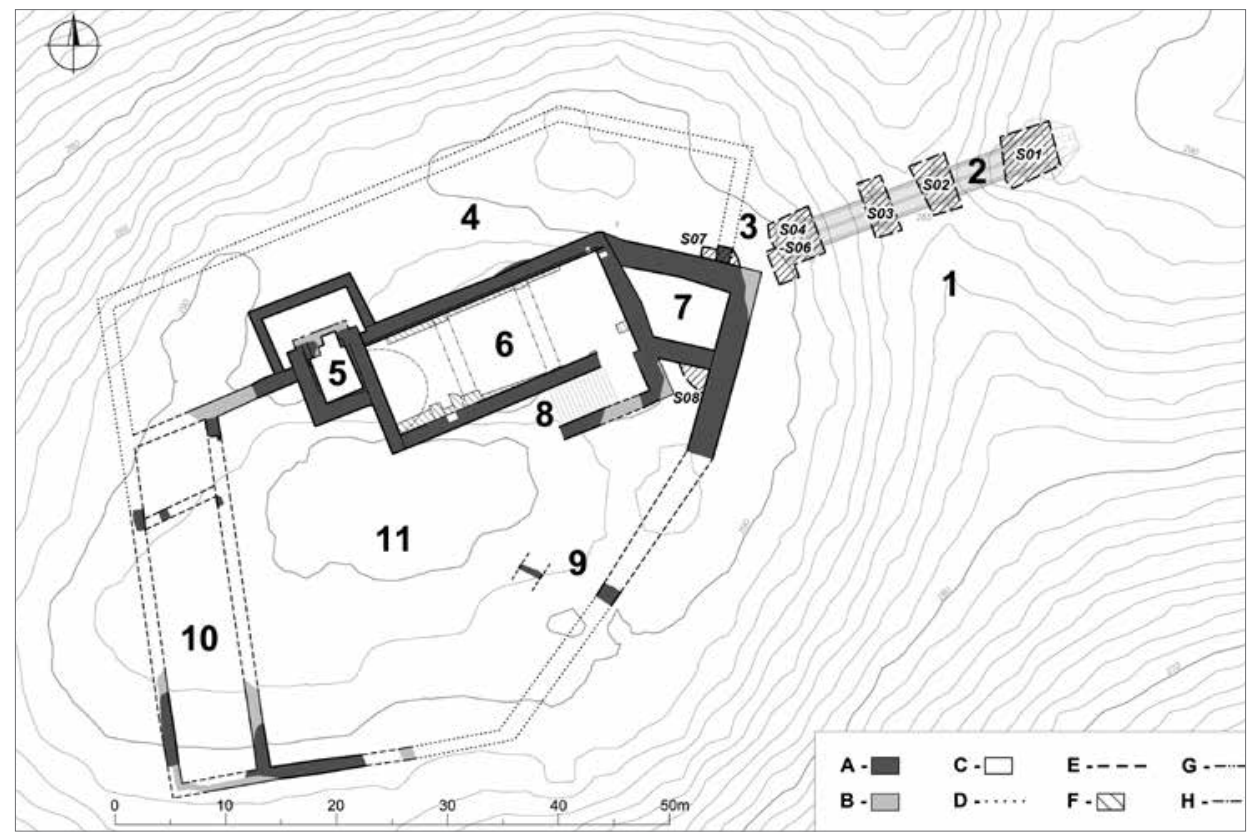

Obr. 10. Nový hrad u Kunratic. Půdorysný plán hradu s vyznačením archeologických sond (S01-S08) a jednotlivých stavebních komponent areálu: 1 - šíjový př́ikop, 2 - nový most, 3 - předpokládané místo první brány, 4 - severní parkánový prostor, 5 - druhá průjezdná brána s vlčí jámou a příkopem, 6 - velký (severní) palác, 7 - východní (věžovité?) zakončení paláce s břitem, 8 - schodišt’ový př́stavek se šíjovým vstupem do suterénu velkého paláce, 9 - nedochované jihovýchodní a jižní křídlo hradu, 10 - nedochované západní kř́́dlo hradu, 11 - nádvoř́; A - dochované konstrukce, B - konstrukce dokumentované př́i odkryvu v letech 1928-1929, C - nedochované konstrukce, D - hypotetický průběh konstrukcí, E - vysoce pravděpodobná rekonstrukce průběhu konstrukcí, F - cihlové konstrukce dokumentované při odkryvu v letech 1928-1929, dnes dochovány pouze částečně, G - nedochované klenební pasy suterénu paláce, $\mathrm{H}$ - nedochovaná klenba suterénu. Na podkladě nového geodetického zaměření zpracoval J. Hlavatý, grafická úprava F. Flek, NPÚ.

Abb. 10. Wenzelsburg bei Kundratitz. Grundrissplan der Burg mit eingezeichneten archäologischen Sondierschnitten (S01-S08) und den einzelnen Baukomponenten des Areals: 1 - Halsgraben, 2 - neue Brücke, 3 - mutmaßliche Lage des ersten Tors, 4 - Bereich des nördlichen Zwingers, 5 - Zweites Durchfahrtstor mit Wolfsgrube und Graben, 6 - großer (nördlicher) Palas, 7 - östlicher (turmartiger?) Palasabschluss mit Prallkeil, 8 - Treppenanbau mit Kehleingang zum Souterrain des großen Palas, 9 - nicht erhalten gebliebener Südost- und Südflügel der Burg, 10 - nicht erhalten gebliebener Westflügel der Burg, 11 - Hof; A - erhaltene Konstruktion, B - bei der Freilegung von 1928-1929 dokumentierte Konstruktionen, C - nicht erhalten gebliebene Konstruktionen, D - hypothetischer Verlauf von Konstruktionen, E - sehr wahrscheinliche Rekonstruktion des Verlaufs von Konstruktionen, F - bei den Freilegungen von 1928-1929 dokumentierte Backsteinkonstruktionen, heute nur teilweise erhalten, G - nicht erhalten gebliebene Gewölbegurte des Palassouterrains, $\mathrm{H}$ - nicht erhalten gebliebenes Gewölbe des Souterrains. Anhand einer neuen geodätischen Vermessung erstellt von J. Hlavatý, grafische Bearbeitung F. Flek, Nationalinstitut für Denkmalpflege.

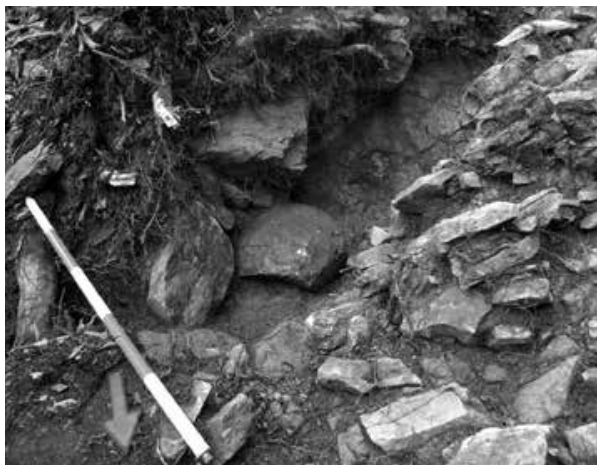

ve své bázi na skalní podklad, který na jižní straně klesal směrem $\mathrm{k}$ severu. $\mathrm{V}$ této partii převažovaly větší lomové kameny o rozměrech až $0,5 \mathrm{~m}$ a nahodilé, tvarově jednoduché, kamenicky opracované články z opuky. Mezi bází destrukce zdi a skalním podkladem se místy nalézala tenká vrstvička prachovité hlíny s vyšším podílem uhlíků (mocnost $2 \mathrm{~cm}$ ) a při samé hraně sondy i vrstvička maltoviny. V této situaci se nalézalo torzo kamenné prakové koule, překryté volnější kamennou destrukcí (obr. 11). Antropogenně upravené

Obr. 11. Nový hrad u Kunratic. Destrukce obvodové hradby severního parkánového prostoru s nálezem prakového projektilu, v prostoru předpokládaného vstupu do hradu, spojené sondy S04-S06, pohled od severovýchodu. Foto F. Flek, NPÚ.

Abb. 11. Wenzelsburg bei Kundratitz. Zerstörungsschicht der Außenmauer des nördlichen Zwingerbereichs mit Schleuderprojektilfund im Bereich des mutmaßlichen Burgeingangs, miteinander verbundene Sondierschnitte S04-S06, Blick von Nordosten. Foto F. Flek, Nationalinstitut für Denkmalpflege. 
skalní podloží zde tvořila ukloněná vrstva našedle bílé lavice pískovců (nepravidelný průběh povrchu v rozmezí nivelet 290,82 až 290,24 mn.m.; Podliska 2012, 30-32; Flek-Podliska-Semerád 2014, 14).

\section{Sondy S05 a S06}

Odlišnou terénní situaci přinesly sousední, jižně situované sondy S05 a S06. Výrazněji nestratifikované souvrství prachovité hlíny s příměsí kamenů do $10 \mathrm{~cm}$ zde zaplňovalo výkop s rovným dnem zahloubený do skalního podkladu (povrch sondy $291 \mathrm{~m} \mathrm{n}$. m.). Skalní podloží zde bylo čisté, beze stop malty na svém povrchu (niveleta dna v rozmezí 290,55 až 290,35 mn. m.). Pouze na východní straně se nalézala do skály vytesaná kapsa, možný pozůstatek založení blíže neznámé vertikální konstrukce (Podliska 2012, 32-33).

\section{Sonda S07}

V prostoru vlastního hradu byly situovány pouze dvě sondy S07 a S08 (obr. 10). Sonda S07 se nalézala při vnější straně východního zakončení palácové stavby, místa označovaného jako stavba s břitem (obr. 10:7). K obvodové stěně zde přiléhal terénní útvar indikující možnou prrítomnost zbytku zaniklé konstrukce první brány. V nepravidelném výkopu o rozměrech stran ca $3,7 \times 1 \mathrm{~m}$ se zde podařilo odhalit materiálově nesourodou kamennou destrukci zdiva složeného z lomových prachovců, nehojně říčních valounů a zvětralé malty, přiléhající kolmo k vnějšímu líci zdi palácové stavby. Báze destrukce nasedala na zarovnané skalní podloží, místy s nálepy malty. Výška destrukce činila $\mathrm{v}$ maximu $0,7 \mathrm{~m}$. Výška vlastního obvodového zdiva východní části paláce zde kolísala mezi třemi až sedmi nepravidelnými řádky lomových prachovců, spojovaných hrubozrnnou vápennou maltou (obr. 12). Základová spára byla rovná, usazená př́mo

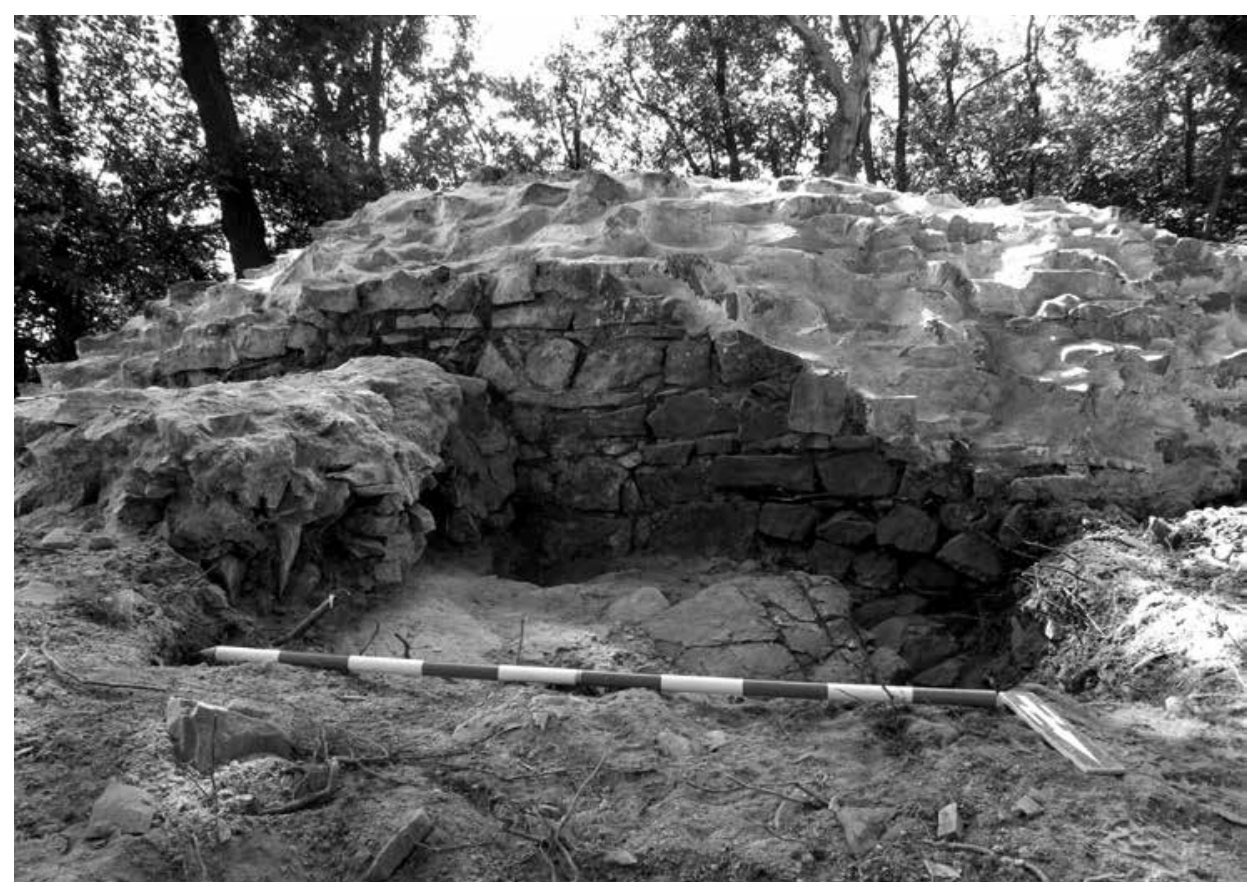

Obr. 12. Nový hrad u Kunratic. Struktura severního líce obvodové zdi východního zakončení palácové stavby s břitem, zčásti odkryté archeologickým výzkumem v roce 2013, sonda S07, pohled od severu. Foto F. Flek, NPÚ.

Abb. 12. Wenzelsburg bei Kundratitz. Struktur der Nordflucht der Außenmauer des östlichen Palastbauabschlusses mit Prallkeil, während der archäologischen Grabung von 2013 teilweise freigelegt, Sondierschnitt S07, Blick von Norden. Foto F. Flek, Nationalinstitut für Denkmalpflege. 


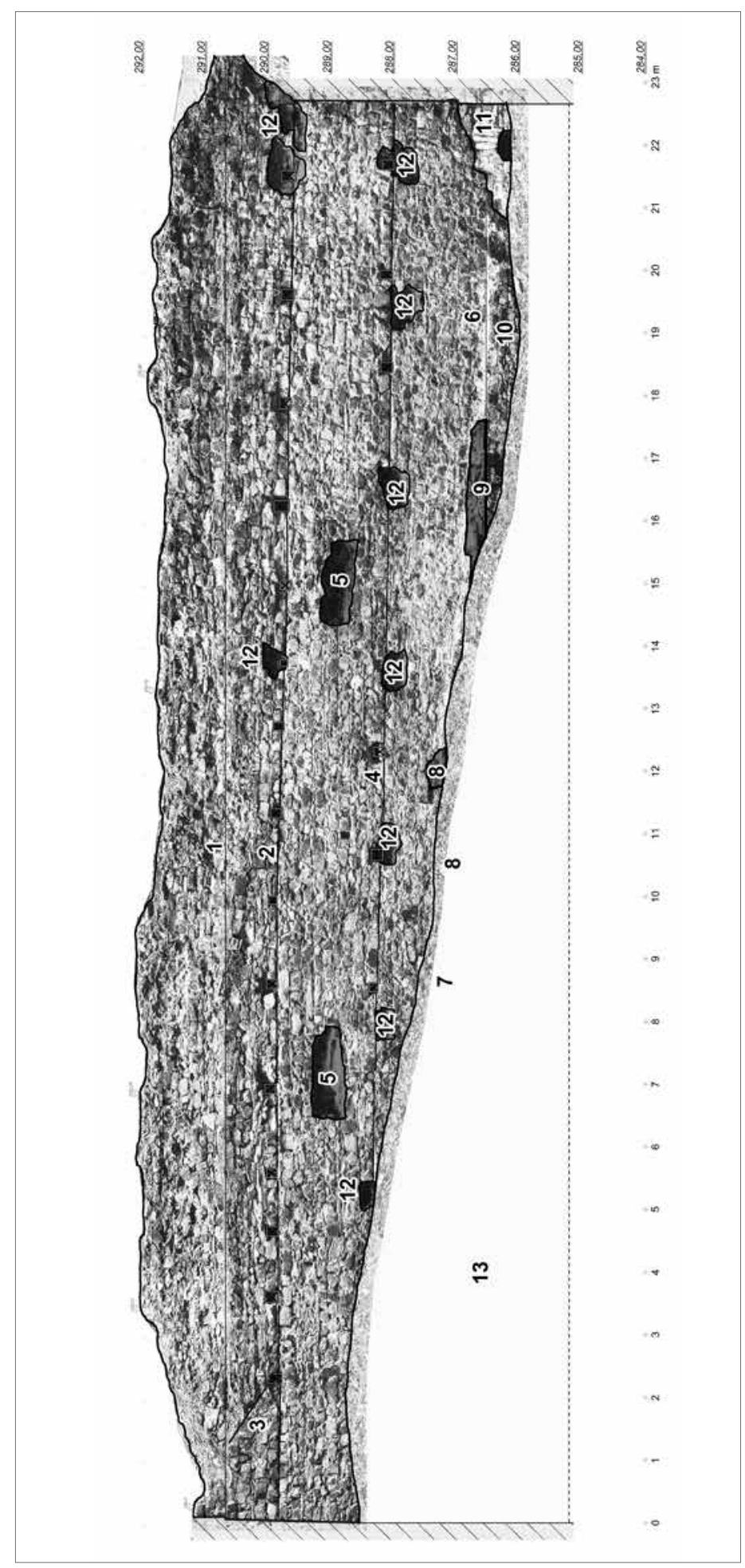

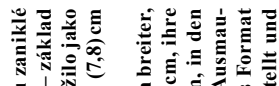

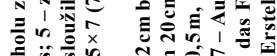

हैं की लै

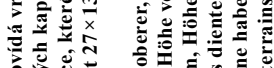

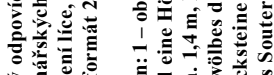

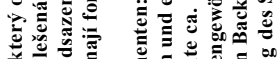

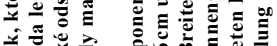

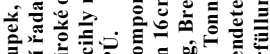

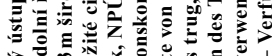

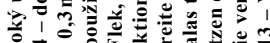

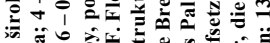

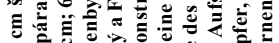

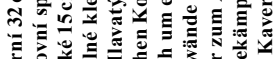

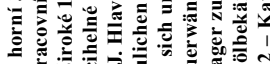

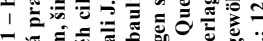

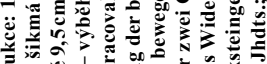

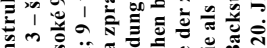

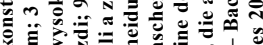

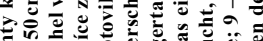

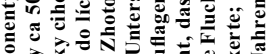

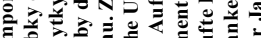

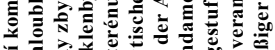

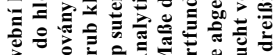

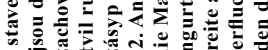

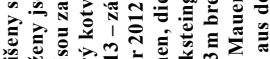

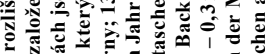

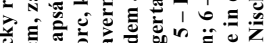

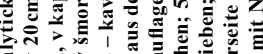

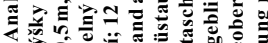

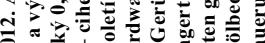

ปิ่

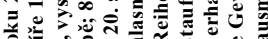

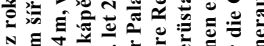

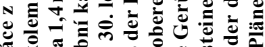

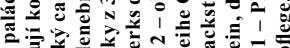

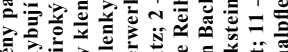

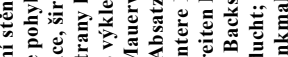

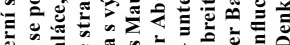

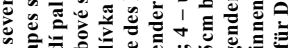

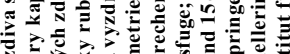

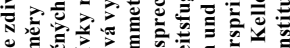

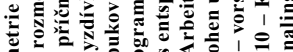

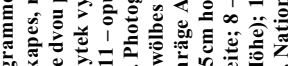

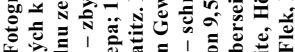

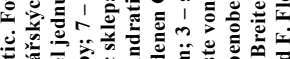

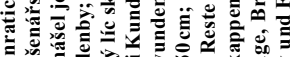

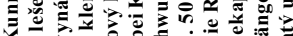
=

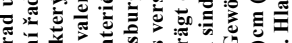

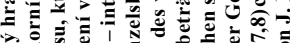

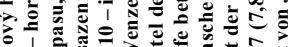

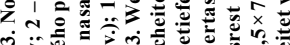

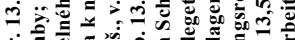

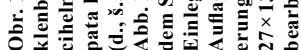


na skalní podklad do maltového lože (niveleta 290,86 m n.m.; Podliska 2012, 35-37; Flek-Podliska-Semerád 2014, 14-15).

\section{Sonda S08}

Poslední sonda výzkumu S08 se nacházela při jižní straně zdi, situované mezi palácem a obvodovou hradbou (obr. 10). Šlo o výkop ve tvaru trojúhelníku o rozměrech stran 2,8, 2,2 a 3,5 m. Důvodem pro její realizaci byla snaha ověřit vzájemný vztah mezi jižní zdí a obvodovou hradbou. Pod lesní hrabankou s recentními odpadky se nacházela pouze vrstva zvětralého prachovce s př́měsí hlíny o mocnosti $0,1-0,4 \mathrm{~m}$, překrývající skalní podklad. Zed' přiléhala na spáru k hlavní obvodové zdi hradu. Její základová partie opět nasedala bez známek náročnějšího základu přímo na skalní podloží (niveleta $290,30 \mathrm{~m} \mathrm{n}$. m.), v západní části byla vynesena recentním betonovým překladem (Flek-Podliska-Semerád 2014, 15).

\section{Operativní průzkum a dokumentace dochovaných konstrukcí hradu}

V roce 2010 nechal Magistrát hlavního města Prahy zpracovat standardní stavebně historický průzkum hradu (Valtr 2010), který měl sloužit jako podklad k přípravě projektu na statické zajištění rozpadající se hradní zříceniny. Hned v úvodu sám autor tohoto průzkumu doporučuje během realizace projektu prohloubit získané poznatky podrobnou dokumentací. I to byl jeden z důvodů, proč jsme v létě roku 2012, kdy vrcholily přípravné stavební práce (odstraňování náletové zeleně), přistoupili k operativnímu průzkumu a dokumentaci vnitřních líců obvodového zdiva paláce, hradní brány a revizi zaměření (Flek-Podliska-Semerád 2014). Při tom se podařilo objevit dosud nikdy nedokumentované části hradu. Zároveň jsme se snažili komparovat současný stav se zaměřením objektu před a po zahájení archeologického odkryvu v letech 1928 a 1929 (obr. 4, 5), kdy byla detailně zaměřena pouze centrální část hradu: palác, k východu natočený břit pláštové hradby a průjezdná brána s př́ikopem na západní straně paláce. Vzniklý plán odlišuje cihelné zdivo valené klenby a kamenné zdivo obvodových zdí. Celá řada tehdy odkrytých konstrukcí a stavebních detailů při srovnání se stavem před zahájením konzervace bud'to zcela zanikla, či splynula s povrchem terénu. Tuto skutečnost nejlépe ilustruje zaměření současného stavu (obr. 10), do něhož jsou světle šedou barvou promítnuty konstrukce zaměřené roku 1929.

Od vlastního průzkumu jsme neočekávali, že by mohl odhalit starší vývojové fáze. Víme, že hrad byl postaven za poměrně krátkou dobu a sám o sobě nesloužil svému účelu o mnoho déle. Hlavní díl našeho bádání se tedy soustředil na co možná nejpřesnější popis současného stavu: popis konstrukčních detailů a identifikaci technologického postupu výstavby. To vše s vědomím, že po provedeném zajištění rozpadajících se torz zdiv se změní vypovídací hodnota objektu. Obecně platí, že sebelépe míněná konzervace stírá rozdíl mezi původním a doplněným, což pak mnohdy vyvolává zcela liché představy o původní podobě památky. Sami jsme se o tom mohli přesvědčit při identifikaci dvou výklenků v severovýchodním rohu paláce, kde nebýt dobové fotodokumentace, byla by jejich interpretace přinejmenším diskutabilní. Případným pochybnostem se dá předejít jedině naprosto precizním zachycením výchozího stavu, které pak bude do budoucna $\mathrm{k}$ dispozici při jakékoliv další údržbě. A dále dokumentací skutečného provedení stavby, zde bychom spíše řekli skutečného provedení konzervace, které se od původního projektu může značnou měrou lišit.

V našem prŕípadě se podařilo realizovat všechny tyto fáze. Nejdříve byly vyhotoveny fotogrammetrické plány líců dotčených konzervačními zásahy s př́íslušným rozborem, které si všímaly nejenom konstrukčních detailů, ale i míry jejich poškození. V samém závěru po provedené konzervaci následovala kompletní digitalizace celého jádra s použitím laserového skenování a stereofotogrammetrie (Kutišová 2014; Larina 2014).

Nový hrad u Kunratic byl vystavěn na konci protáhlého a mírně vyvýšeného ostrohu, odděleného od zbytku př́íčným prríkopem (obr. 10). Ze stavebního hlediska dnes můžeme sledovat pouze některé jeho dochované části. Nejvýrazněji zde vystupuje pozůstatek podsklepeného velkého paláce, situovaného v podélné ose ostrohu do čela hradu, kde byl od východu chráněn 


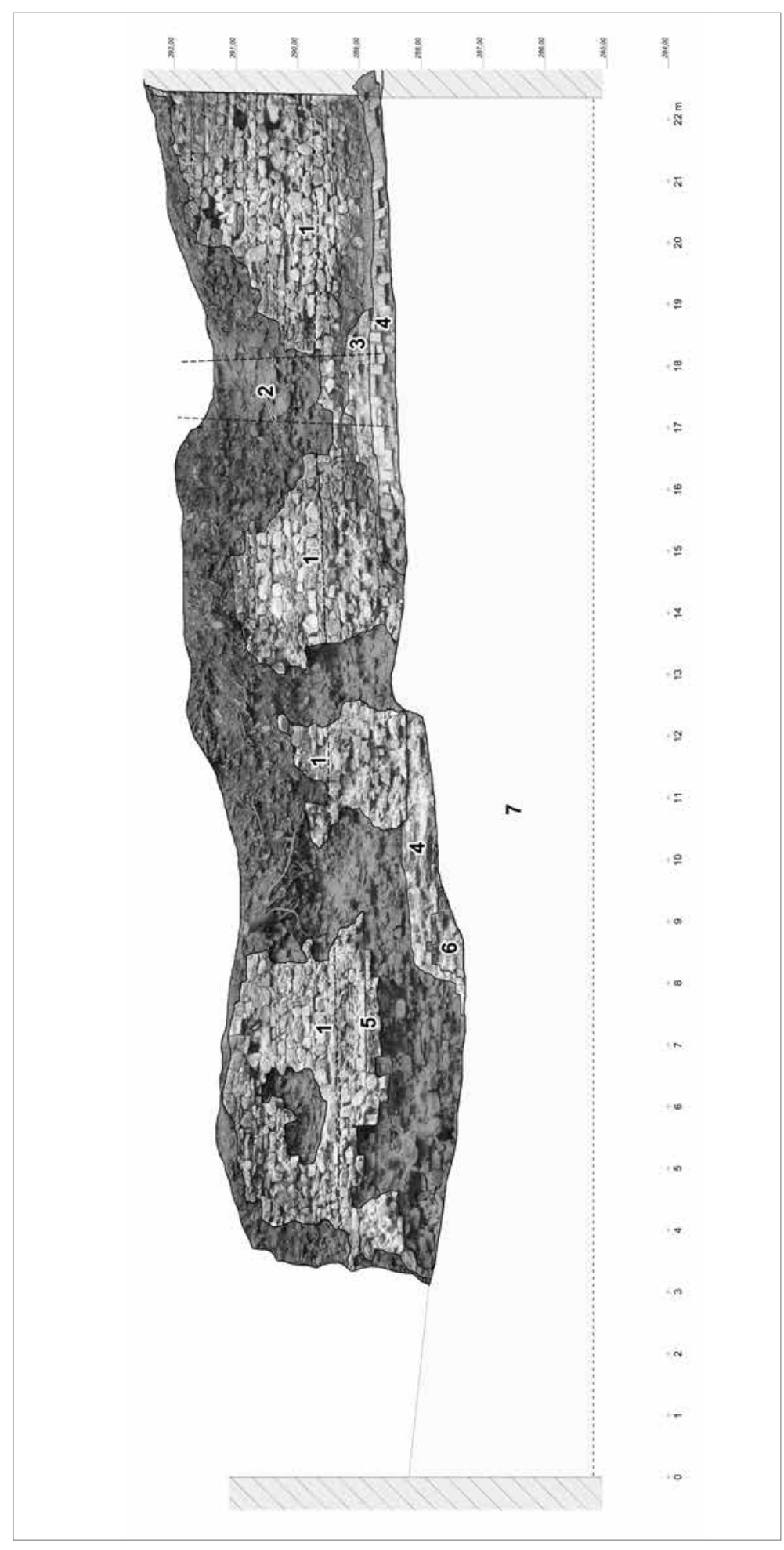

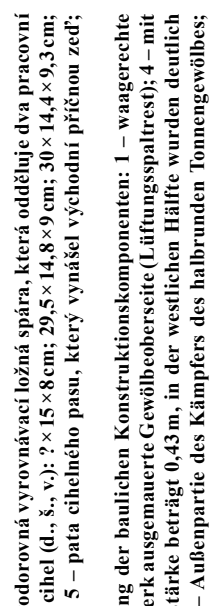

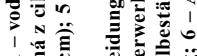

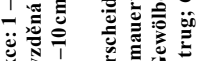

उo

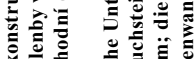

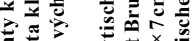

政造

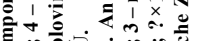

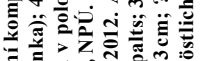

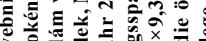

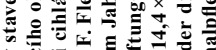

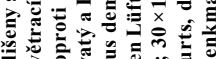

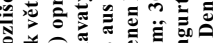

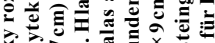

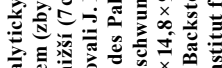

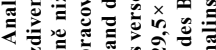

4 N

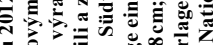

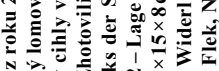

을

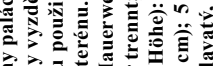

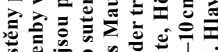

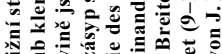

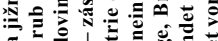

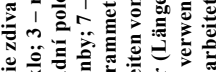

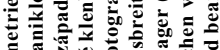

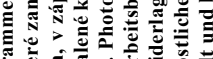

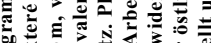

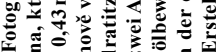

을

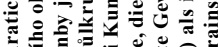

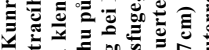

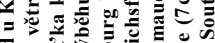

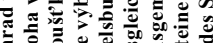

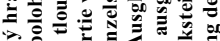

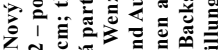

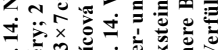

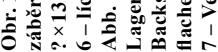




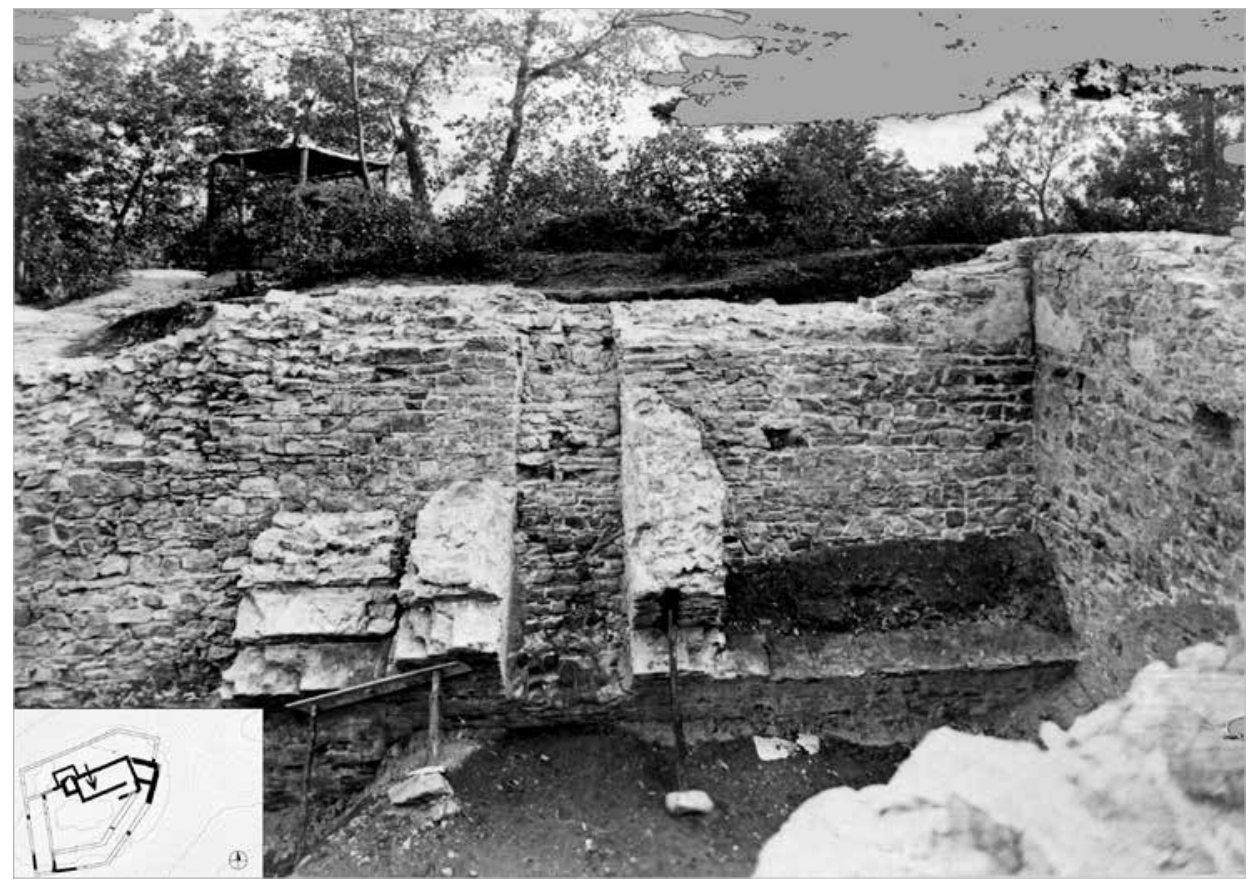

Obr. 15. Nový hrad u Kunratic. Detailní záběr na jižní stěnu suterénu velkého paláce s torzem klenebních pasů a větracího okna, pohled od severu. Stav při jejich odhalení v letech 1928 a 1929. ARÚ AV ČR, Praha, FT000081746.

Abb. 15. Wenzelsburg bei Kundratitz. Detailaufnahme der Südwand des Souterrains des großen Palas mit Gewölbegurtorso und Lüftungsfenster, Blick von Norden. Zustand bei ihrer Freilegung im Jahr 1928 und 1929. Archäologisches Institut der Tschechischen Akademie der Wissenschaften, Prag, FT000081746.

nepodsklepenou částí s výrazným břitem, tvořící plášt’ovou hradbu o síle až $2,6 \mathrm{~m}$. Rekonstrukce této části je bohužel značně problematická. Snad mohlo jít o věžový útvar, či přímo věž, která svou hmotou chránila vlastní palác. Sama pláštová hradba vymezovala hradní areál s nedochovanou obvodovou zástavbou především na jeho jižní a západní straně. Západní stranu uzavíralo prř́čné dvorní křídlo, které se táhlo přes celé návrší v délce $34 \mathrm{~m}$ a šířce $9,1 \mathrm{~m}$. Obvodové zdi západního křídla dosahují tloušt'ky $1,15 \mathrm{~m}$. Oproti obvodovým zdem hlavního paláce o tloušt'ce 1,3-1,4 m jsou tak nepatrně tenčí. Ve vnitřní dispozici západního křídla byla na severním konci zachycena koruna suterénní př́ičné zdi rovnoběžná $\mathrm{s}$ osou královského paláce, a tudíž orientovaná šikmo k podélným zdem západního kř́ila. Vymezuje s vysokou pravděpodobností podsklepený prostor široký šest metrů, který byl větrán nejméně jedním oknem, jehož severní omítanou špaletu s částí strmého bankálu jsme odhalili ve východní obvodové zdi (obr. 18). Mezi ním a západním koncem paláce byla vložena průjezdná brána s př́ikopem obráceným do úzkého předbraní - parkánového prostoru na severní straně paláce. Jde o protáhlou plošinu lemovanou dnes vyvýšenými terénními relikty, které mohou ukrývat pozůstatky blíže nepoznaného obvodového opevnění. Ty můžeme sledovat podél celé severní strany hradního jádra a zčásti i na západním konci ostrohu. $Z$ vnitřní zástavby se na jihovýchodní straně nádvoří zachoval ve vzdálenosti 5,1 m od vnitřního líce pláštové hradby relikt s ní rovnoběžné $2 \mathrm{~m}$ silné zdi, který je dokonce o více než $0,3 \mathrm{~m}$ silnější než vlastní pláštová hradba. Relikt tohoto zdiva vybíhá z profilu, který vznikl těžbou lomového kamene. Další průběh zdi jsme neměli možnost zkoumat. Zřejmě však jde o pozůstatek dvorního křídla, které přiléhalo k vnitřní straně pláštové hradby.

Nejvíce pozornosti při operativním průzkumu bylo věnováno pozůstatkům velkého paláce o velikosti $25,8 \times 11,5 \mathrm{~m}$ s rozměrným suterénem. Obvodové zdi zde nepřesahují sílu 1,2-1,4 m. Nedochovaná nadzemní podlaží byla rozdělena dvojicí příčných zdí, které nesly půlkruhové 
pasy kopírující rub půlkruhově valené cihlové klenby suterénu. Relikty těchto zdí a vynášecích pasů s částmi prolomené klenby zřetelně zachycují fotografie pořízené při archeologickém výzkumu L. Jansové (obr. 6,8 ). Suterén o rozměrech $22,5 \times 8,5 \mathrm{~m}$ je dnes v nejhlubším místě zasypán do výšky klenebních patek (obr. 7,9). Jeho podlahová úroveň však byla ve východní části dosažena při archeologickém výzkumu. Dochované zbytky zdí jsou zde odhaleny do výše až $4,15 \mathrm{~m}$.

U líců, které se měly konzervovat, byly pořizeny podrobné fotogrammetrické plány, do nichž se zakresloval rozbor nálezových situací a také projekt konzervace.

Severní obvodovou zed' suterénu člení po výšce dva ústupky (obr. 13:1, 6). Do spodního se opírala pata cihelné klenby (obr. 13:9). Horní zřejmě upravoval tloušt'ku nadzemního zdiva (obr. 13:1). Po vynášecích pasech, které nesly př́ičné zdi, se zde zachovaly mělké kapsy vyplněné zbytky cihelného zdiva (obr. 13:5). Levá, západní kapsa je široká $1,4 \mathrm{~m}$ a vysoká $0,5 \mathrm{~m}$. Pravá, východní kapsa je široká $1,3 \mathrm{~m}$ a vysoká $0,48 \mathrm{~m}$. V líci zdi se v pravidelných rozestupech, převážně $1,3 \mathrm{~m}, \mathrm{v}$ menší míře až $1,6 \mathrm{~m}$, rýsují dvě řady lešenářských kapes. Také na západní a východní obvodové zdi pozorujeme vrstvy pracovních záběrů vysoké 1,4 až 1,6 m oddělené řadami lešenářských kapes (obr. 13:2). Z rozložení lešenářských kapes lze vypozorovat vzájemný posun někdy až o polovinu osové vzdálenosti mezi jednotlivými kapsami. Nastíněné rozložení lešenářských kapes poukazuje na propojení podlážek svislými prvky, sloupky, přičemž spodní poskytovaly oporu ob jednu výše položeným, které ještě nebyly zatíženy nadezděným zdivem.

Archeologický výzkum na konci 20. let 20. století odkryl na vnitřním líci západní obvodové zdi paláce zbytek interiérové omítky přitažené k původní podlaze přízemí, která se nacházela na niveletě $291,95 \mathrm{~m}$ n. m. Níže se rýsoval obrys čela valené klenby, který byl nahozen vrstvou hrubé omítky (obr. 6). Zbytky těchto povrchových úprav již zcela zanikly.

Stav jižní obvodové zdi bylo možné před zahájením konzervačních prací označit za havarijní. A přitom ještě ve 30. letech 20. století nebyl výrazněji poškozen (srovnej obr. 14 a 15). Líc stěny zde plošně destruoval hluboko do jádra zdi. Poškození bylo zjevně způsobeno zatékáním do zdiva. Realizovaný projekt ji dnes řeší odtokovými kanálky. Největší podíl destruovaného zdiva odpovídal poloze zapuštěného bankálu větracího okna (obr. 14:2, 15), které procházelo klenbou a stoupalo šikmo ostře vzhůru nad terén. V líci jižní obvodové zdi jsme nenalezli žádné lešenářské kapsy. Je možné, že byl vyzděn z přiloženého lešení. Při bázi odhaleného líce jsou zachovány cihelné výběhy půlkruhově valené klenby (obr. 14:4). Ve východní polovině zcela výjimečně z cihel vysokých až $9 \mathrm{~cm}$, které jsou zapuštěny do líce zdi. V západní polovině je použit formát cihel vysoký $7 \mathrm{~cm}$.

K jihovýchodnímu nároží paláce přiléhají dnes pozůstatky schodištového prŕístavku s pravotočivou vstupní šíjí do palácového sklepa. K jeho odhalení došlo při výzkumu L. Jansové, jak zřetelně zachycují dochované plány (obr. 5), tak dobové fotografie (Durdík 1984, 181, obr.6). Viditelně zde vystupují široké, do skalního podkladu vytesané stupně schodiště, po nichž dnes již zůstaly zachovány pouze nevýrazné terénní relikty překryté lesním substrátem a nízkou vegetací.

Ve východní obvodové zdi jsou nad terénem zachyceny čtyři pracovní záběry. Jižní polovina líce, včetně líce schodištové šíje, je znehodnocena neodborně provedenými vysprávkami z přelomu 20. a 30. let 20. století, které vůbec nerespektovaly původní členění konstrukce a materiálovou skladbu (provedeny jsou z kvádrového namísto ložného kamene, který je spojován křiklavě šedou cementovou maltou).

Západní stranu paláce uzavíral objekt průjezdné věžové brány o velikosti 7,1×6,8 m, s kolébkovým mostem, který překonával zděný prŕíkop o rozměrech $5 \times 8 \mathrm{~m}$. Tak jako palác je i objekt brány zachován pod úrovní terénu, s nepatrným zbytkem nadzemního zdiva, které se odlišuje nevýrazně odsazeným lícem. Portál na vnitřní straně brány byl opatřen odrazníky čtvrtkruhové profilace, jak dokládá snímek pořízený při archeologických vykopávkách v letech 1928-1929. Stavební zajímavostí brány je přítomnost zčásti zasypaného podzemního prostoru pod průjezdem, tzv. vlčí jámy, o šířce 3,5 m a délce 4,1 m. Čelní obvodová zed' prostoru vlčí jámy mírně vystupuje do př́ikopu a je zesílena konstrukcí př́izedního pilíře, jehož nároží jou armována 
opracovanými opukovými kvádry. Na její vnitřní straně je vytvořen prostor pro uložení pohyblivých částí kolébkového mostu. Vlevo je to vertikální kapsa zčásti zapuštěná do západní obvodové zdi. Následuje širší vpadlina pro vlastní pojezdnou plochu mostu, s mostovku o šířce $1,95 \mathrm{~m}$ zatíženou protizávažím. A nakonec zde registrujeme lavicové rozšíření, které přiléhá k východní obvodové zdi.

Rozborem styčných spár u jednotlivých konstrukcí se podařilo určit technologický postup výstavby hradního jádra - velkého paláce, průjezdné brány a břitového zakončení paláce. Předpokládáme, že výstavba byla zahájena vyrubáním skalního podloží pro suterén paláce. Vyrubaný kámen byl s vysokou pravděpodobností použit jako stavební materiál, který byl dále doplňován o materiál z těžby hradního příkopu. Podélné zdi paláce, severní a jižní, přiléhají na západě k čelní obvodové zdi, o kterou se dělí s přístavkem průjezdné brány. $Z$ toho vyplývá, že stavba paláce postupovala od západu: nejprve byla založena brána, ke které se postupně přidaly obě podélné zdi paláce. Na jeho východním konci se pak pokračovalo se stavbou opevnění.

Z míry dochování obvodových konstrukcí je zjevné, že demolice hradních staveb roku 1881 směřovala zejména ke zničení výrazné dominanty velkého paláce, zatímco opodál stojící zrrícenina západního a jižního křídla byla $v$ této době patrně již ve větším rozsahu archeologizována. Nová zjištění nám tak dávají naději do budoucna, že pod současným povrchem jsou stále zachovány části dispozice této stavby, a to včetně možného suterénního podlaží (obr. 18).

\section{Památková péče a konzervace zř́íceniny}

Stav Nového hradu u Kunratic na počátku 21. století byl katastrofální a některým jeho stavebním částem hrozil definitivní zánik. Situaci zvrátil záměr provést přemostění př́ikopu a stavební sanaci zříceniny, administrovaný pracovníky dnešního Odboru městské zeleně a odpadového hospodářství Magistrátu hlavního města Prahy. Projekční a přípravné práce probíhaly v letech 2009 až 2012, stavební realizace během let 2012 a 2013. Odborný památkový dohled zajištovali pracovníci Národního památkového ústavu, územního odborného pracoviště v Praze, kteří provedli rozsahem nevelký záchranný archeologický výzkum zaměřený na komplexní památkovou dokumentaci hradní zříceniny a reliktů obléhacího tábora husitských vojsk.

Od počátku soudobého zájmu o Nový hrad, který odstartoval již opakovaně zmíněný archeologický výzkum Libuše Jansové, se věnovala nemalá pozornost následné konzervaci odhalených konstrukcí. $Z$ dnešního úhlu pohledu bychom mohli pokládat některé zásahy za diskutabilní. Poškozené části líců byly neodborně přezděny, nerespektovalo se jejich původní členění, vrstvy lomového zdiva ani původní materiál. V severovýchodním koutě paláce byly vytvořeny zavádějící novotvary dvou výklenků. Jinde se naopak volil zcela technicistní postup - podepírání kaveren železobetonovými nosníky (např. jižní stěna východního zakončení paláce, obvodová stěna př́ikopu před druhou bránou). Veškeré odhalené líce byly navíc bez rozmyslu plošně přespárovány tak, že se zcela setřel jejich vypovídací charakter. Ten se naštěstí po několika desetiletích degradace více méně vrátil k původnímu stavu - spáry byly vyplaveny.

Srovnáním současné a dobové fotodokumentace pak dále zjišt'ujeme, že koruny obvodových zdí paláce destruovaly i o několik desítek centimetrů (obr. 6, 7, 8, 9, 14, 15, 16, 17). Stalo se tak i přes následně provedenou konzervaci odhalených zdiv. Podobný osud stihl zbytky povrchových úprav. Naprosto tragicky se ovšem jeví destrukce odhalených výběhů kleneb se špaletami větracího okna na jižní stěně paláce (obr. 14, 15), která zjevně hrozila již krátce po odkrytí. Co však lze považovat za skutečně nenahraditelnou ztrátu, je zničení vrchní části čelní obvodové zdi průjezdné brány mezi prostorem vlčí jámy a příkopem, která obsahovala složitě řešené uložení kolébkového mostu. Jeho podobu tak alespoň známe z historických snímků (obr. 16).

Realizace projektu na zajištění Nového hrádku u Kunratic se zhostil ateliér obnovy a konzervace historických staveb GIRSA AT spol. s r. o. (Girsa 2012; Hanzl 2014, 343-345). Dokumentaci pro ohlášení stavby a návrh mostní lávky zpracovala firma PSK TUZAR, s. r. o. Vlastní realizaci stavby provedla firma Haniš - rekonstrukce a opravy historických staveb s. r. o. Projekt se zaměřil na opravu hradního jádra - suterénu velkého paláce, druhé brány s vyzděným př́í- 


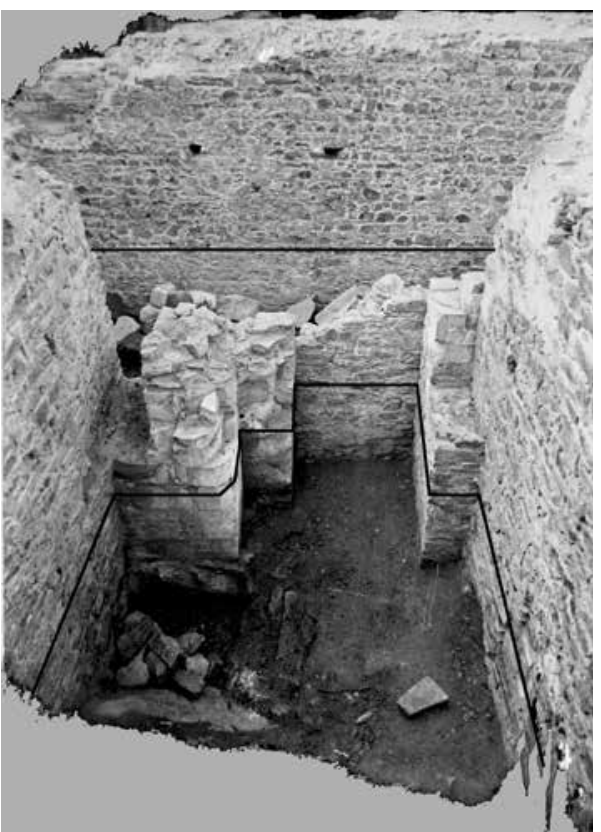

Obr. 16. Nový hrad u Kunratic. Podzemní prostor tzv. vlčí jámy pod průjezdem druhé brány, pohled od jihu. Stav při jeho odhalení v letech 1928 a 1929. Cernou čarou vyznačena úroveň dnešního terénu. ARÚ AV ČR, Praha, FT000081716.

Abb. 16. Wenzelsburg bei Kundratitz. Unterirdischer Raum der sog. Wolfsgrube unter der Durchfahrt des zweiten Tors, Blick von Süden. Zustand bei ihrer Freilegung in den Jahren 1928 und 1929. Die schwarzen Linien kennzeichnen das heutige Höhenniveau des Geländes. Archäologisches Institut der Tschechischen Akademie der Wissenschaften, Prag, FT000081716.

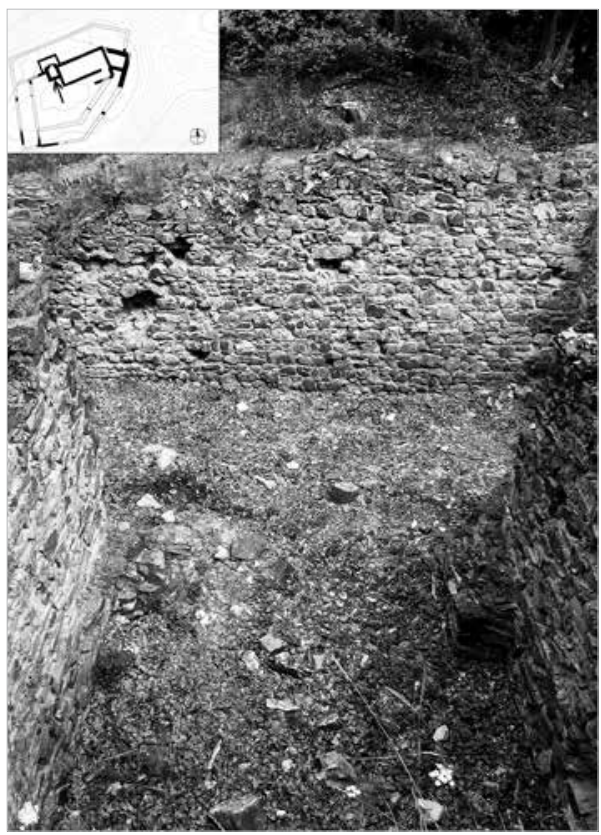

Obr. 17. Nový hrad u Kunratic. Srovnávací foto k obr. 16, stav objektu před zahájením rekonstrukčních prací v roce 2012. Foto F. Flek, NPÚ.

Abb. 17. Wenzelsburg bei Kundratitz. Vergleichsfoto zu Abb. 16, Zustand des Objekts vor Beginn der Rekonstruktionsarbeiten im Jahr 2012. Foto F. Flek, Nationalinstitut für Denkmalpflege.

kopem a východního zakončení paláce se zbytky břitu pláštové hradby. Prakticky šlo o ty části hradu, které byly vykopány L. Jansovou. Relikty obvodové zástavby na jihu a západě areálu nebyly vzhledem $\mathrm{k}$ jejich stavu předmětem konzervačních prací.

Na základě vzniklého projektu bylo přistoupeno $\mathrm{k}$ velice šetrnému způsobu konzervace splňujícímu metodické standardy pro opravy uvedených typů památkových objektů (Sokol-Durdík-Štulc 1998). Poškozené části obvodových zdí se opravovaly jen v nejnutnější míře. Nejdříve byly zhodnoceny podle různé míry degradace jako zdivo s mělkou spárou, zdivo s hlubokou spárou a zdivo poškozené na jádrové zdivo. Označily se nejen kaverny, ale i veškeré mladší zásahy. Šlo zejména o líce, kde bylo použito cementové pojivo. To však neznamená, že veškeré mladší zásahy byly odstraňovány. Přihlíželo se k tomu, že pokud nejde o opravy, které by ohrožovaly stabilitu konstrukcí, není nutné přistupovat $\mathrm{k}$ jejich výměně. Ta by totiž v jistých případech vedla k poškození původního zdiva. Fixace zdiva chemickými postřiky se neprováděla vůbec. $\mathrm{O}$ to větší pozornost byla věnována příčinám degradace zdiv, které stály za rychlým průběhem degradace, tj. zatékající dešt'ové vodě a v menší míře i zemní vlhkosti. $Z$ tohoto důvodu se přistoupilo k jílové izolaci obnažených korun zdí a jejich osazení travním drnem, což zamezí intenzivnímu prosakování deštové vody či tajícího sněhu, a tedy rozrušování a rozpadu zdiv.

Kulturní památce se tak po desetiletí nezájmu dostalo šetrné konzervace všech dochovaných autentických konstrukcí hradu. Nově byl vybudován dřevěný most přes hradní příkop $\mathrm{s}$ bezbariérovým přístupem a bezpečnostní ohrazení v místech hradního sklepa a brány. Hlavní město Praha jako vlastník památky investovalo do obnovy hradního areálu 2,9 milionu korun, nově instalovaný informační systém v podobě panelů stál kolem 500 tisíc korun a stavba mostu 
2,7 milionu korun. Díky dobré spolupráci všech zúčastněných subjektů se celou akci podařilo uskutečnit bez větších provozních komplikací v relativně krátké době.

\section{Shrnutí poznatků}

Dnes je hrad převážně archeologickou památkou, přičemž určitá část jeho pozůstatků je v rozdílné podobě a stavu ukryta pod současným povrchem. Dochované nadzemní části hradu byly $\mathrm{v}$ různé míře postiženy rozpadem, a to především $\mathrm{z}$ důvodu celkové absence údržby po jejich odkryvu v letech 1928 až 1929. Nové odborné vyhodnocení stavby si vytklo v prvé řadě za úkol památkové zhodnocení stavu hradních objektů a jejich částí, a to za využití všech dostupných historických pramenů a technických podkladů. Ve druhém kroku pak dokumentaci stávajících pozůstatků hradních staveb. Zaměření hradu a terénní konfigurace jeho okolí, které sloužilo projektové přípravě, nebylo pro účely operativní dokumentace a ani archeologického výzkumu dostatečně přesné. Bylo tedy přistoupeno k reviznímu zaměření dochovaných reliktů, které se provádělo v součinnosti mezi geodetem, archeologem a stavebním historikem. Co do rozsahu nezůstalo soustředěné pouze na jádro hradu samé, ale věnovalo se i vnější části fortifikace, jako byl mělký př́ikop obíhající severozápadní stranu hradního kopce. Archeologické aktivity nevystoupily $\mathrm{v}$ této etapě poznávání $\mathrm{z}$ rámce záchranné činnosti v místech stavebního zásahu. Realizovaný výzkum v prostoru šijového příkopu a ve východní části hradního jádra přinesl paradoxně první informace o podobě historického nadloží a stavu dochování hradních konstrukcí. Zcela zásadní součástí archeologické akce se stal i operativní průzkum a dokumentace hradních konstrukcí, jejichž cílem bylo zachycení stavu památky před provedením konzervačních zákroků a poznání dosud zachovaných konstrukčních a technologických stop na dochovaných konstrukcích bývalého hradu. $Z$ provedené dokumentace a vyzvednutých nálezů vyplynuly následující poznatky (obr. 10).

Geologický základ místa je na celé ploše hradního areálu tvořen pestrou směsicí skalních uloženin starohorního a prvohorního stáří. Jde především o pevné kompaktní vrstvy prachovců nazelenalé a hnědé barvy, případně šedé břidlice. Skalní podklad místy vystupuje až na současný povrch (sondy S01, S02), nebo je př̌kryt různě mocným a strukturovaným souvrstvím př́rodních či antropogenních uloženin rozdílné mocnosti (od 0,1 až do 2,3 m). Ve vlastním jádru hradu je velice problematické rozlišit intaktní historické uloženiny z doby jeho existence a situace druhotně přemístěné. Povrch skalního podkladu byl v minulosti radikálně pozměněn především při stavebních zásazích spjatých s výstavbou hradu (sondy v př́ikopu S02 a S03; zásahy na vnitřní straně hradního příkopu v areálu hradu, S04 až S08), v menší míře v době mladší, kdy zde probíhala těžba kamene (jižní část areálu), a v neposlední řadě při provedení archeologického výzkumu na sklonku 20. let 20. století. Průběh skalního podkladu dodnes názorně přibližují stěny hradního př́kopu.

Archeologické sondy z prostoru hradního příkopu a na jeho předpolí (S01 až S06) nezachytily žádné pozůstatky, které by bylo možné spojit s př́stupovou cestou či konstrukcí hradního mostu. Terén zde byl značně postižen erozí, místy až na skalní podklad (S01). Dvojice sond v př́kopu (S02 a S03) zastihla značně jednoduchou situaci, kde obsahově homogenní vrstvy svahové sutě překrývaly nikterak výrazněji upravený skalní podklad. Jedinými nálezy v nadložní vrstvě tak zůstaly nepočetné fragmenty kamenicky opracovaných, avšak slohově prostých architektonických článků. Zbylá část sondy S04 (sloučené s S05 a S06) již dokumentovala stav pozůstatků hradního areálu na jeho východní straně - na hraně př́íkopu, v místech, kde je dosavadním bádáním lokalizována první hradní brána (Menclová 1972, 177-178; Durdík 1984, 180). Pod vrstvou lesního substrátu se na severní straně odkrývané plochy objevila mohutná destrukce zděné konstrukce, snad obvodové hradby severního prostoru - parkánu, u které předpokládáme sesunutí do nitra areálu a do jeho př́kopu. Vzhledem k rozsahu odkryvu není možné uvedený nález konkrétněji popsat. Nález zlomku prakové koule v jeho tělese můžeme bezpochyby spojit s bojovou operací na přelomu let 1420 a 1421, kdy byl v jejím závěru hrad záměrně rozbořen. Dílčí informace o podobě založení hradních staveb a míře jejího zachování přinesla 


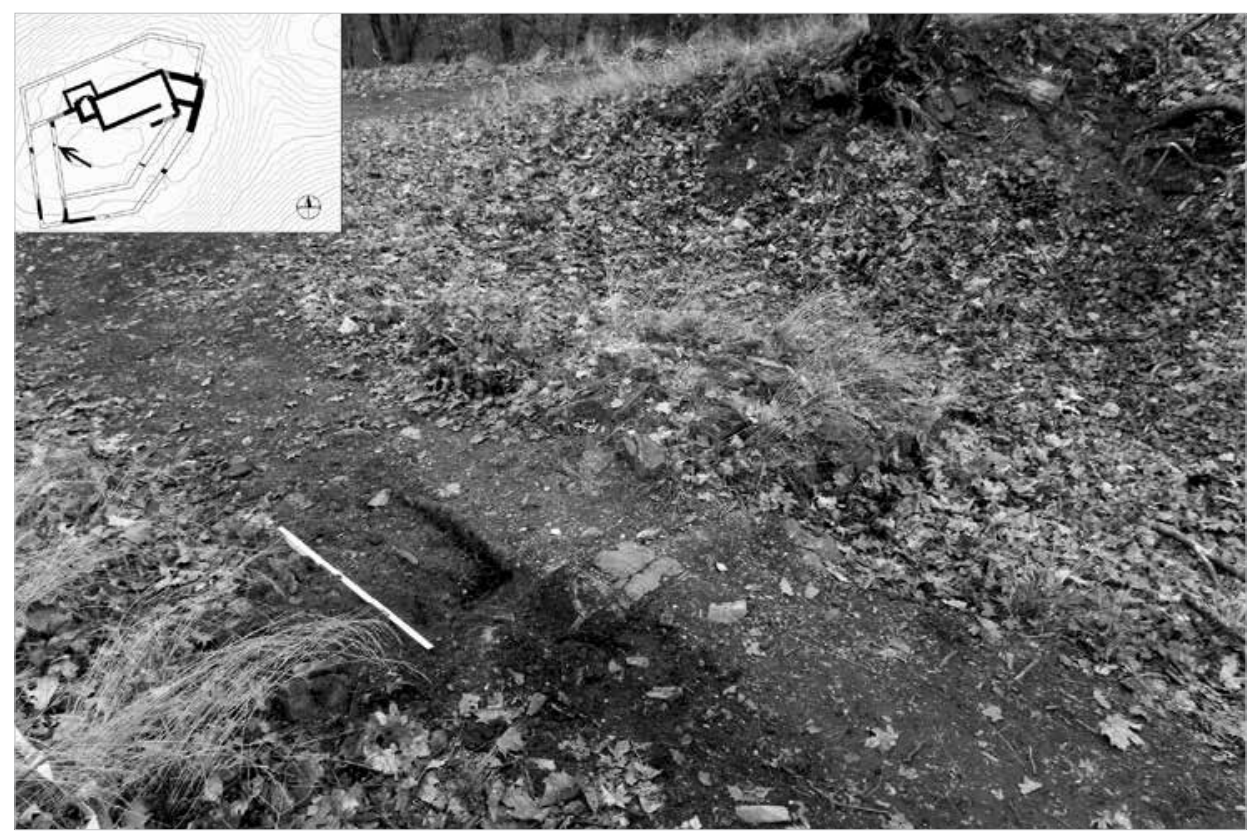

Obr. 18. Nový hrad u Kunratic. Nález pozůstatků špalety a části bankálu na koruně zdi předpokládaného palácového objektu v západní části areálu, pohled od jihovýchodu. Stav v roce 2013. Foto F. Flek, NPÚ.

Abb. 18. Wenzelsburg bei Kundratitz. Fund der Laibungsüberreste und Fenstersimsteile auf der Mauerkrone des mutmaßlichen Palasobjektes im Westteil des Areals, Blick von Südosten. Zustand im Jahr 2013. Foto F. Flek, Nationalinstitut für Denkmalpflege.
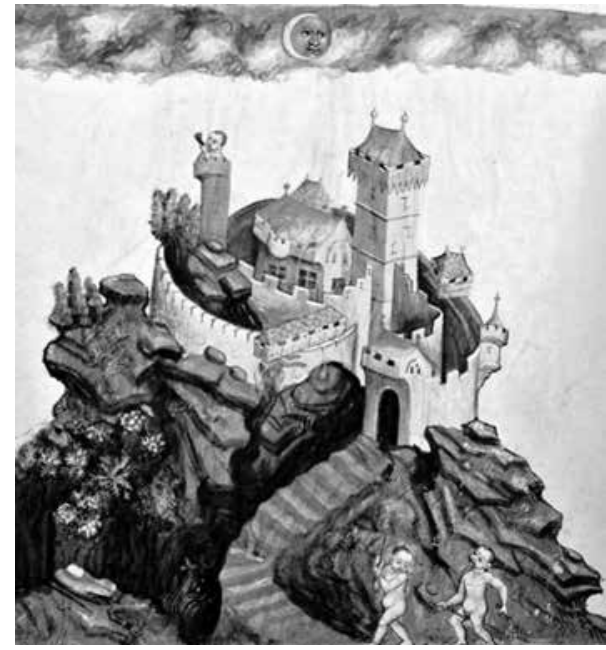

Obr. 19. Dobové vyobrazení neznámého hradu v rukopisu Bellifortis od Konráda Kyesera z Eichstättu (1366 - asi 1405), které při srovnání s pozůstatky Nového hradu u Kunratic nebývale věrně zachycuje hmotové uspořádání hradní stavby a jeho částí. MS Philos 63, Universitätsbibliothek Göttingen, fol. 94. Podle Záruba 2014.

Abb. 19. Zeitgenössische Darstellung einer unbekannten Burg in der Handschrift Bellifortis von Konrad Kyeser aus Eichstätt (1366 - um 1405), die bei einem Vergleich mit den Überbleibseln der Wenzelsburg bei Kundratitz die Baumassenanordnung der Burgbauten und ihrer Teile ungewöhnlich naturgetreu wiedergibt. Göttingen, Staats- und Universitätsbibliothek, Ms. philos 63, Fol. 94. Nach Záruba 2014. nevelká sonda S07, umístěná na severní straně obvodové zdi čela hradu (stavby s břitem). V místech nápadného terénního reliktu, který mohl být interpretován jako pozůstatek zaniklé zdi (snad součásti první hradní brány, nebo ohrazení parkánového prostoru), se nalézalo velice nesourodé seskupení lomových kamenů promíchaných s hrudkami zvětralé malty, uložené na skalní podklad bez náznaku provázání s přiléhající obvodovou hradbou. Jestli šlo původně o zděnou konstrukci, nelze na základě zachyceného stavu potvrdit. Uvedený př́klad pouze názorně demonstruje aktuální stav části hradního areálu, kde některé partie hradu již definitivně zanikly. Dochované zdivo staveb vystupující nad úroveň dnešního terénu je $\mathrm{v}$ převaze mělce založeno na zarovnaný skalní podklad. Jeho mocnost dosahuje rámcově pouze několika řádek kamenů ( $\mathrm{S} 07$ a S08). Výjimku zde tvoří pouze sklep paláce a druhá hradní brána s př́kopem.

Mezi operativní zjištění patří dokumentace zbytků náběhu na cihlovou klenbu v suterénu paláce, které jsou pod současnou úrovní zásypu jeho interiéru stále dochovány. Západně od druhé brány pak nález pozůstatků 
špalety a části bankálu situované na koruně zdi předpokládaného západního palácového objektu, který může obsahovat i dosud neznámé podzemní prostory (obr. 18).

Nově získané poznatky bychom rádi využili i při pokusu o novou hmotovou rekonstrukci hradu a jeho části. Práce na tomto úkolu již byly autory př́ispěvku před časem zahájeny. Jako možný doplňkový zdroj informací pro tuto práci nám mohou být v převaze anonymní dobová vyobrazení hradních staveb, která při bližším srovnání s dochovanými objekty až překvapivě věrně zachycují tehdejší realitu (obr. 19).

Záchranný archeologický výzkum společně s operativní stavební dokumentací i přes svůj nevelký rozsah přinesl nové informace o podobě hradu a postupu jeho zániku. Provedená stavební obnova hradního jádra v letech 2012-2013 postupovala metodou šetrné konzervace všech dochovaných autentických konstrukcí hradu, a to včetně konstrukčních detailů. Pouze u partií, které se zcela rozpadly (část jižní zdi sklepa paláce), př́ípadně vykazovaly známky výrazného stavebního a statického narušení, došlo k doplnění konstrukce autentickým materiálem způsobem odpovídajícím použité dobové stavební technologii a formě.

Současná podoba celého areálu je tak ve stavu, který dává naději, že jeho pozůstatky zde zůstanou zachovány i pro další generace zájemců a obdivovatelů této hradní stavby (obr. 20).

Za pomoc při zpracování dokumentace a př́ipravě podkladů pro článek děkujeme řadě kolegů, jmenovitě především Františku Flekovi, Vladimíru Gutovi a Jakubu Hlavatému z NPÚ HMP. Dále Janu Hrdinovi za pomoc při znovuobjevení a zprostředkování historického plánu hradu z fondů Archivuhl.m. Prahy. Poděkování též patří redaktorce Českého rozhlasu Adrianě Krobové za vytrvalý zájem a přípravu řady rozhlasových pořadů o minulosti této památky a Ing. arch. Anně Anděrové z Odboru městské zeleně a odpadového hospodářství Magistrátu hl. m. Prahy, bez níž by celá oprava hradu nebyla taková, jaká byla.

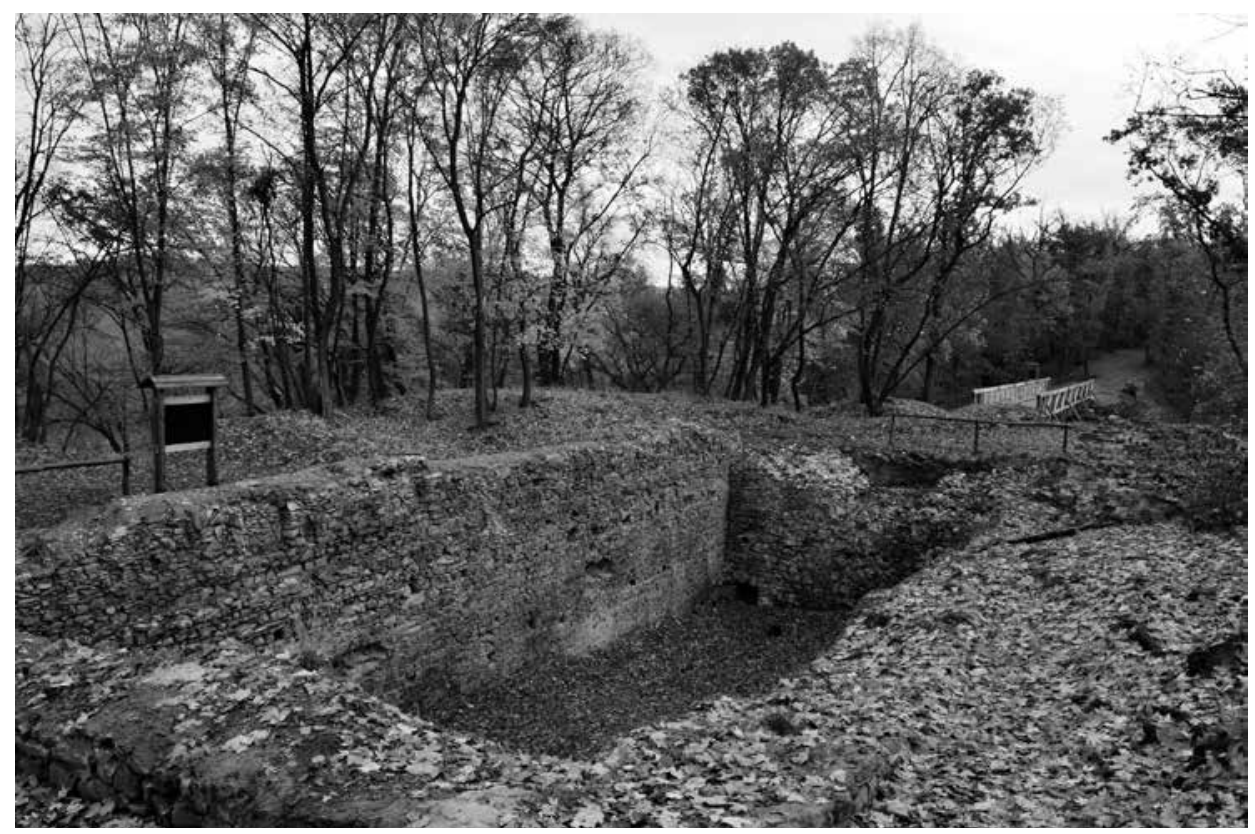

Obr. 20. Nový hrad u Kunratic. Stav hradního objektu v roce 2013 po provedených památkových úpravách a konzervaci hradního zdiva. Pohled od jihozápadu na sklep paláce, v pozadí nový most přes př́íkop. Foto J. Podliska, NPÚ.

Abb. 20. Wenzelsburg bei Kundratitz. Zustand des Burgobjekts im Jahr 2013 nach erfolgten denkmalpflegerischen Maßnahmen und Konservierung der Burggemäuer. Blick von Südwesten auf den Palaskeller, im Hintergrund neue Brücke über den Graben. Foto J. Podliska, Nationalinstitut für Denkmalpflege. 
Příspěvek vznikl v rámci výzkumného cíle „Archeologie“ Národního památkového ústavu, financovaného z institucionální podpory Ministerstva kultury na dlouhodobý koncepční rozvoj výzkumné organizace (DKRVO).

\section{Prameny a literatura}

AČ VII: Archiv český čili staré písemné památky české i moravské, sebrané z archivů domácích i cizích (Kalousek, J., ed.). Praha 1887.

AČ XXVI: Archiv český. Zpráva o statcích a přech venkovských z archivu města Prahy, A-K (Teige, J., ed.). Praha 1906.

BALBÍN, B., 1986: Krásy a bohatství české země. Praha.

DROBNÁ, Z., 1953: Husitský polní tábor u Kunratic, Historie a vojenství 2, 197-200.

- 1971: V Praze před 550 lety: Výstava k výročí dobývání královského Nového hradu husitskými Pražany 1420-1421, Národní muzeum, scénář. Praha.

DURDÍK, T., 1980: K chronologii keramiky 14. - počátku 15. století ve východní části středních Čech - Zur Chronologie der Keramik des 14. - bis Anfang des 15. Jahrhunderts im Ostteil Mittelböhmens, AH 5, 361-368.

- 1984: Nový Hrad u Kunratic (Praha 4) a jeho postavení ve vývoji české hradní architektury - Nový Hrad bei Kunratice (Prag 4) und seine Stellung in der Entwicklung der böhmischen Burgenarchitektur, Archeologica Pragensia 5, 173-190.

- 1986: Hrady Václava IV. v pražských městech a jejich nejbližším okolí - Die Burgen von Wenzel IV. in den Prager Städten und in ihrer nächsten Umgebung. In: Praha - město ve válkách a revolucích. Documenta Pragensia VI, 24-46. Praha.

- 1999: Ilustrovaná encyklopedie českých hradů. Praha.

FLEK, F.-PODLISKA, J.-SEMERÁD, M., 2014: Nálezová zpráva, záchranný archeologický výzkum a operativní průzkum a dokumentace, NPÚ, ÚOP v hl.m. Praze, 2012/39, 2013/39, Praha - Kunratice, Nový hrad u Kunratic ppč. 863/1, čj. 311/54136/2014, ulož. v archivu NZ NPÚ, ÚOP v hl. m. Praze.

FRB V: Fontes rerum Bohemicarum V, Kronika Vavřince z Březové (Emler, J., ed.). Praha 1893.

GIRSA AT s.r.o., 2012: Akce: Nový hrádek u Kunratic. Č́st: zajištění a konzervace torza zdiva hrádku dokumentace pro výběr zhotovitele stavby, 1. Technická zpráva, 22, ulož. v archivu odboru archeologie NPÚ ÚOP HMP.

HANZL, M., 2014: Konzervace torza Nového hrádku v Praze - Kunraticích, ZPP 74, 343-345.

HARTL, J., 1971-1972: Eponyme Fundstelle Knovíz. Fontes Archeologici Pragenses 15. Pragae.

HLAVÁČEK, I., 1962: Studie k diplomatice Václava IV., IV. Itinerář krále Václava IV. (1361-1419), ČČH 10, 64-94.

KŘIVÁNEK, R., 2014: Geofyzikální průzkum v areálu husitského obléhacího tábora na předpolí Nového hradu v Praze-Kunraticích - Geophysical survey on the grounds of the Hussite siege camp in the foregrounds of Nový hrad in Prague-Kunratice, AR LXVI, 633-650.

KUTIŠOVÁ, M., 2014: Nový hrad u Kunratic - tvorba detailního 3d modelu vybrané části, nepubl. bakalářská práce na Fakultě stavební ČVUT v Praze.

KYPTA, J.-PODLISKA, J., 2014: Tábor obléhatelů na předpolí Nového hradu u Kunratic (1420/1421). Povrchový průzkum a srovnání s analogickými lokalitami - The Hussite field camp from the siege of Nový hrad at Kunratice (1420/1421). Surface survey and a comparison with parallel sites, AR LXVI, 609-632.

LARINA, A., 2014: Nový hrad u Kunratic - tvorba detailního 3d modelu vybrané části, nepubl. bakalářská práce na Fakultě stavební ČVUT v Praze.

MENCLOVÁ, D., 1972: České hrady 2. Praha.

MERHOUT, C., 1902: Kaple na Novém hradě, Method XXXVIII, 97-99.

- 1912: Čtení o Novém Hradě a Kunraticích. Praha.

NEUWIRTH, J., 1893: Geschichte der bildenden Kunst in Böhmen vom Tode Wenzels III bis zu den Husitenkriegen. 1. Band. Prag.

PODLAHA, A., 1908: Soupis památek historických a uměleckých v politickém okresu Vinohradském. Praha.

PODLISKA, J., 2012: Nálezová zpráva, záchranný archeologický výzkum NPÚ, ÚOP v hl.m. Praze, 2012/20, Praha-Kunratice, Nový hrad u Kunratic ppč. 863/1, archiv NZ NPÚ, ÚOP v hl.m. Praze, čj. 62789/2012, př. č. TX-2013-2173, ulož. v archivu NZ ARÚ AV ČR, Praha, v. v. i.

SEDLÁČEK, A., 1927: Hrady, zámky a tvrze království Českého. Díl patnáctý. Praha. 
SOKOL, J.-DURDÍK, T.-ŠTULC, J., 1998: Ochrana, údržba a stavební úpravy zř́icenin hradů. Odborné metodické publikace, sv. 17. Př́loha ZPP 58. Praha.

VALTR, L., 2010: Nový hrad u Kunratic. Stavebně historický průzkum Parc. č. 863/1, k. ú. Kunratice, nepubl. zpráva, ulož. v archivu odboru archeologie NPÚ ÚOP HMP.

ZÁRUBA, F., 2014: Hrady Václava IV. Od nedobytného útočiště k pohodlné rezidenci. Opera Facultatis theologiae catholicae Universitatis Carolinae Pragensis. Historia et historia artium 17. Praha.

ZAVŘEL, J., 2012: Přírodní prostředí. In: Podliska, J., Nálezová zpráva, záchranný archeologický výzkum NPÚ, ÚOP v hl.m. Praze, 2012/20, Praha - Kunratice, Nový hrad u Kunratic ppč. 863/1, 9-14.

\section{Zusammenfassung}

\section{Die Wenzelsburg bei Kundratitz (Nový Hrad u Kunratic) in Prag. Grabung und Wieder- aufbau des zerfallenden Burgbaus}

In den Jahren 2009 bis 2013 erfolgten in der Geschichte der Burg die ersten umfangreichen Instandsetzungsarbeiten des Areals sowie eine vollumfängliche Konservierung der erhaltenen Bauten. Im Rahmen dieser Maßnahme wurden dort in Verbindung mit einer Dokumentation der erhaltenen Burgreste archäologische und bauhistorische Arbeiten durchgeführt. Die Wenzelsburg bei Kundratitz zählt zu den bedeutenden Burgbauten der Zeit Wenzels IV., die zu Beginn des zweiten Jahrzehnts des 15. Jahrhunderts auf dessen Veranlassung hin errichtet wurden. Ihr früher und gewaltsamer Untergang im Jahr 1421 macht aus ihr eine absolut datierbare Fundstelle. Dieser Bau steht bereits über ein Jahrhundert lang im Interesse der historischen Forschung (C. Merhout). In den Jahren 1928 bis 1929 erfolgte dort eine der ersten archäologischen Freilegungen eines Burgbaus auf dem Gebiet der damaligen Tschechoslowakei (L. Jansová), die leider bis heute jedoch nicht fachgerecht ausgewertet wurde. Die freigelegten Bauten wurden in der Vergangenheit baulich nicht untersucht, sodass es im Laufe des 20. Jahrhunderts zu ihrem allmählichen Zerfall kam. Die neue fachgerechte Auswertung des Baus hat es sich in erster Linie zur Aufgabe gemacht, den Zustand der Burgobjekte und ihre Teile denkmalpflegerisch zu ermitteln, und zwar unter Heranziehung aller verfügbaren historischen Quellen und technischen Unterlagen. Im zweiten Schritt dann die Dokumentation der bestehenden Überreste der Burgbauten, einschließlich einer Revisionsvermessung der erhaltenen Relikte. Was den Umfang anbelangt, konzentrierte man sich nicht nur auf die Kernburg selbst, sondern widmete sich auch den äußeren Teilen der Befestigung wie etwa dem flachen Graben, der die Nordwestseite des Burghügels umschloss. Die archäologischen Aktivitäten gingen in dieser Erkenntnisetappe an den Stellen, an denen bauliche Eingriffe vorgenommen wurden, nicht über den Rahmen von Rettungsarbeiten hinaus. Die im Bereich des Halsgrabens und im östlichen Teil der Kernburg durchgeführte Grabung lieferten paradoxerweise erste Informationen über die Form des historischen Firstes und über den Zustand der erhaltenen Burgkonstruktionen. Das geologische Fundament des Ortes wird über die gesamte Fläche der Burg durch eine bunte Mischung Ablagerungen von Felsen gebildet, die beim Bau der Burg verwendet wurden, oder ist von einer verschieden starken und verschieden strukturierten Schichtenfolge bedeckt, die aus überwiegend natürlichen bzw. anthropogenen Ablagerungen von geringer Stärke besteht. In der eigentlichen Kernburg ist es sehr problematisch, zwischen intakten historischen Ablagerungen aus der Zeit, als sie noch existierte, und den sekundär verlagerten Situationen zu unterscheiden (Gesteinsabbau, archäologische Ausgrabungen von L. Jansová). Die eigentliche Oberfläche des Felsenuntergrundes wurde in der Vergangenheit vor allem durch solche bauliche Eingriffe radikal verändert, die mit dem Umbau der Burg zusammenhingen. Durch die archäologischen Sondiergrabungen im Bereich des Burggrabens und seines Vorfeldes (S01 bis S03) wurden keine Überreste festgestellt, die man mit dem Zugangsweg oder der Konstruktion der Burgbrücke in Verbindung bringen könnte. Durch die am inneren Rand des Areals erfolgten Sondiergrabungen (S04 bis S06) wurde die Zerstörungsschicht einer Mauer freigelegt, bei der es sich wohl um die Außenmauer eines Zwingers oder um die Überreste des Eingangstors in der Wehrmauer handelt. Den Fund eines Schleuder- 
kugelbruchstücks im Mauerwerkskörper können wir zweifellos mit den Gefechtsoperationen der Jahreswende 1420/1421 in Verbindung bringen, die schließlich zur zielstrebigen Zerstörung der Burg geführt haben. Über die Form der Gründung der Burgbauten und über ihren Erhaltungsgrad gaben die Sondierschnitte S07 und S08 Auskunft. Sie ergaben, dass die erhalten gebliebenen Reste der Burgkonstruktion direkt auf einem Felsenuntergrund gegründet sind und dass ihre Stärke in etwa nur einige Steinreihen erreichte. Eine Ausnahme machen hier der Keller des Palas und das zweite Burgtor mit Graben. Zu den operativen Feststellungen zählt die Dokumentation der Dienste des Backsteingewölbes im Souterrain des Palas, die unter dem heutigen Höhenniveau der Verfüllung seines Interieurs immer noch erhalten sind. Die Unterscheidung von einer Reihe von Konstruktionselementen im Souterrain des großen Palas, im Bereich des zweiten Tors und der völlig neue Fund von Laibungsüberresten und Fenstersimsteilen auf der Mauerkrone des heute bereits verschwundenen Palaswestflügels ergänzen unsere Kenntnisse über diesen Bau um neue Details. Aus denkmalpflegerischer Sicht wurde den Überresten der Burg eine schonende Konservierung aller erhalten gebliebenen Konstruktionen zuteil. Neu gebaut wurde die Holzbrücke über den Graben und das Informationssystem der Schautafeln, die die Besucher mit der reichen Geschichte des Baus und seiner Umgebung vertraut machen.

Der vorliegende Beitrag entstand im Rahmen des Forschungsziels „Archäologie“ des Nationalen Denkmalinstituts und wurde durch die institutionelle Fördermaßnahme zur langfristigen konzeptionellen Entwicklung der Forschungseinrichtung (DKRVO) vom Ministerium für Kultur der Republik Tschechien finanziert.

PhDr. Jaroslav Podliska, Ph.D., Národní památkový ústav, územní odborné pracoviště v hlavním městě Praze, Na Perštýně 356/12, 11000 Praha 1, Česká republika, podliska.jaroslav@npu.cz

Ing. arch. Matouš Semerád, Národní památkový ústav, územní odborné pracoviště v hlavním městě Praze, Na Perštýně 356/12, 11000 Praha 1, Česká republika, semerad.matous@npu.cz 
